Estuarine, Coastal and Shelf Science

February 2018, Volume 201, Pages 208-222

http://dx.doi.org/10.1016/i.ecss.2016.10.016

http://archimer.ifremer.fr/doc/00354/46524/

(c) 2016 Elsevier Ltd. All rights reserved.

\title{
Identification of the main processes underlying ecosystem functioning in the Eastern English Channel, with a focus on flatfish species, as revealed through the application of the Atlantis end-to-end model
}

\author{
Girardin Raphaël ${ }^{1,{ }^{*}}$, Fulton Elizabeth A. ${ }^{2}$, Lehuta Sigrid ${ }^{3}$, Savina-Rolland Marie ${ }^{1}$, Thébaud Olivier ${ }^{4}$, \\ Travers-Trolet Morgane ${ }^{1}$, Vermard Youen ${ }^{3}$, Marchal Paul ${ }^{1}$
}

${ }^{1}$ Ifremer, Channel and North Sea Fisheries Research Unit, 150 Quai Gambetta BP 699, 62321, Boulogne-sur-mer, France

${ }^{2}$ CSIRO, Marine and Atmospheric Research, Castray Esplanade, Hobart, TAS, 7000, Australia

${ }^{3}$ Ifremer, Unit of Fisheries Ecology and Modelling, Centre Atlantique, rue de l'lle d'Yeu BP 21105, 44311, Nantes Cedex 03, France

${ }^{4}$ Ifremer, Univ Brest, CNRS, UMR 6308, AMURE, Unité d'Economie Maritime, IUEM, F-29280,

Plouzane, France

* Corresponding author : Raphaël Girardin, email address : raphael.girardin@noaa.gov

\begin{abstract}
:
The ecosystem model Atlantis was used to investigate the key dynamics and processes that structure the Eastern English Channel ecosystem, with a particular focus on two commercial flatfish species, sole (Solea solea) and plaice (Pleuronectes platessa). This complex model was parameterized with data collected from diverse sources (a literature review, survey data, as well as landings and stock assessment information) and tuned so both simulated biomass and catch fit 2002-2011 observations. Here, the outputs are mainly presented for the two focus species and for some other vertebrates found to be important in the trophic network. The calibration process revealed the importance of coastal areas in the Eastern English Channel and of nutrient inputs from estuaries: a lack of river nutrients decreases the productivity of nursery grounds and adversely affects the production of sole and plaice. The role of discards in the trophic network is also highlighted. While sole and plaice did not have a strong influence on the trophic network of vertebrates, they are important predators for benthic invertebrates and compete for food with crustaceans, whiting (Merlangius merlangus) and other demersal fish. We also found that two key species, cod (Gadus morhua) and whiting, thoroughly structured the Eastern English Channel trophic network.
\end{abstract}

Keywords : Ecosystem modelling, Flatfish fisheries, Trophic relationships, Calibration, Atlantis, Eastern English Channel 


\section{Introduction}

Drawing lessons from past failures and successes (Daw and Gray, 2005; Hilborn, 2004; Hilborn et al., 2001), management science has gradually been moving from traditional single-species considerations (Garcia, 1994; Ludwig, 2002; McAllister and Kirchner, 2002; Rosenberg, 2002) towards a comprehensive, ecosystem-based management (EBM) approach building on the full complexity of ecosystem interactions (Botsford et al., 1997; Browman and Stergiou, 2004; Garcia et al., 2003; Pikitch et al., 2004). Although some multispecies models such as the Stochastic Multi-Species (SMS) model are already applied to assess fish stocks (Lewy and Vinther, 2004), these only focus on commercial fish species and top predators interacting with those species (seabirds and porpoises for the model developed in the North Sea) (ICES, 2014), and do not include bottom-up processes (e.g., impact of prey abundance on growth and survival of predator). The Ecosystem Approach to Fisheries (EAF) has been adopted by many management institutions worldwide (Brodziak and Link, 2002; Sinclair and Valdimarsson, 2003). In the EU, the holistic approach to ecosystem and resources management is part of the Marine Strategy Framework Directive (MSFD) (EC, 2008a). Before EBM is implemented, a reasonably thorough understanding is needed on the complex interactions occurring within ecosystems and on how human activities impact those interactions and dynamics. Ecosystem models can help achieve that understanding (Browman and Stergiou, 2004; Fulton et al., 2011a; van Putten et al., 2012; Wilen et al., 2002).

Over the last few decades, interest in ecosystem modelling has grown within both the scientific and fishery management communities (Arkema et al., 2006; Brodziak and Link, 2002; FAO, 2003; Sanchirico et al., 2006) and a range of "end-to-end" models has been developed to emulate the dynamics of marine ecosystems. In some of these models, human activities are considered as a full component of the ecosystem (Leslie and McLeod, 2007), rather than a forcing driver. Ecosystem dynamics are driven by different types of processes, including hydrodynamics, biogeochemistry, habitat characteristics, population life cycles, trophic relationships, as well as interactions with 
human activities. Coupling these different ecosystem components in holistic models is necessary to mimic how these components interact to create the internal dynamics of the ecosystem, and the extent to which such interactions could explain the fluctuations observed in key ecological or exploitation variables, e.g., biomass, catches, fishing effort (Fulton, 2010; Travers et al., 2007). One of the first ecosystem models that included a large set of species groups and trophic connections was Ecopath with Ecosim (EwE) (Christensen and Walters, 2004). EwE models have been parameterized and applied in many ecosystems across the world and often include interaction with human activities. Recently, other models have emerged focussing on the spatial dimensions of fisheries dynamics and fish stocks, such as ISIS-Fish (Mahévas and Pelletier, 2004), or taking into account nutrient cycling, food web dynamics, and environmental variability, e.g., OSMOSE (Shin and Cury, 2001, 2004; Travers et al., 2009), APECOSM (Maury et al., 2007), NEMURO.FISH (Kishi et al., 2011), SEAPODYM (Lehodey et al., 2008) and Atlantis (Ainsworth et al., 2012; Fulton et al., 2005, 2007; Kaplan et al., 2012; Savina et al., 2013).

The Eastern English Channel (EEC) ecosystem is characterized by a high biodiversity, and it is subject to intense and diversified human activities, of which fisheries are particularly important, ecologically, economically and socially. Each compartment of this ecosystem has been widely studied (Carpentier et al., 2009) with focus on hydrodynamics (Bailly du Bois and Dumas, 2005; Korotenko et al., 2013), biogeochemistry (Beaugrand et al., 2000; Vanhoutte-Brunier et al., 2008), benthic fauna and substrate (Cabioch and Glaçon, 1975; Ellis and Rogers, 2000; Garcia et al., 2011; Savina and Ménesguen, 2008), larval dispersal (Ellien et al., 2000), nursery grounds (Cugier et al., 2005; Riou et al., 2001; Rochette et al., 2010), fish assemblages (Vaz et al., 2007), fleet dynamics and fishery management (Batsleer et al., 2013; Girardin et al., 2015; Marchal et al., 2015; Tidd et al., 2015), and spatial planning (Delavenne et al., 2012; Ulrich et al., 1999). The EEC is a shallow ecosystem strongly structured by river inputs, mainly from the Seine River on the French side (Carpentier et al., 2009), by the seabed substrate, and by the productivity of benthic invertebrates (Cabioch and Glaçon, 1975; Dauvin and Desroy, 2005; Garcia et al., 2011). We focused more specifically on two commercially 
important flatfish species: sole (Solea solea) and plaice (Pleuronectes platessa). Both species are important for the French, UK, Dutch and Belgian fishing industries which target them to varying degrees. Sole and plaice mainly feed on benthic invertebrates and detritus and are nurserydependent (Riou et al., 2001; Rochette et al., 2010).

The main challenge of this study is to integrate available information on all ecosystem compartments from hydrodynamics to human activities in a single framework, and to use this to successfully emulate recent observations of the EEC. In this study, the extensive Atlantis end-to-end model was applied (Fulton et al., 2005, 2007). Atlantis is currently one of the most comprehensive and up-todate ecosystem model (Plagányi, 2007), and it has successfully been applied to a number of case studies worldwide (Ainsworth et al., 2012; Kaplan et al., 2012; Savina et al., 2013b; van Putten et al., 2013; Fulton et al., 2014). By using the Atlantis platform, we aim at modelling the dynamics of sole and plaice within the EEC ecosystem. Strong drivers of the EEC ecosystem, river inputs and benthic invertebrates dynamics, were combined in Atlantis to comprehensively investigate their influence on the two focus species. This represents a major step forward in the understanding and representation of the EEC ecosystem dynamics.

This paper has two overarching objectives. First, the main challenges and lessons drawn from the sequential calibration of the Atlantis Eastern English Channel (Atlantis-EEC) model were reported, which were previously unknown or not considered. The goodness of fit performance of Atlantis-EEC was evaluated by comparing the outputs of the model with available data over the period 2002-2011 (catches and biomasses). Second, we build on the newly calibrated Atlantic-EEC to get new insights into the key dynamics and processes that structure the EEC ecosystem, which could not necessarily be evidenced with existing data and/or models.

\section{Material and Methods}

\subsection{Model implementation}


The Atlantis-EEC model uses the biophysical, trophic network and fisheries modules of the Atlantis end-to-end modelling framework which is fully detailed in Fulton et al. (2011b). Each sub-model is deterministic and spatially-resolved, using a spatial array of irregular polygons positioned to capture important differences in ecosystem features. Processes are implemented via differential equations, in this case using a time step of 24 hours. The main biological processes in the ecosystem are represented in the model: consumption, production, waste production, movement and migration, predation, recruitment, habitat dependency and mortality. Functional groups can be either biomass pools (mainly used for invertebrates) or age class structured (for vertebrates). The fishing sub-model allows for multiple fleets, each with its own characteristics (including gear selectivity, habitat association, targeting, effort allocation and management structures). The Atlantis EEC model was developed to mimic the average ecosystem functioning of the EEC over the period 2002-2011 during which no considerable change in the ecosystem dynamics was noticed (Auber et al., 2015).

The choices made for the spatial structure, and functional groups are particularly crucial to ensure that the model can effectively reproduce observed dynamics. Therefore we focus here on the way (i) the spatial structure of Atlantis-EEC model was designed, (ii) the physical forcing was implemented, (iii) the functional groups were defined and biological processes were parametrized and (iv) the fishing activity was represented.

\subsubsection{Atlantis-EEC model spatial structure}

Atlantis-EEC model was implemented for ICES Division VIId, which covers approximately $35,000 \mathrm{~km}^{2}$. The design of the spatial structure of the model was based on the biogeography of the EEC. This included spatial differences in physical features of the bottom grounds (i.e. bathymetry, sediment partitioning between soft (mud and fine sand), flat (coarse sand and gravels) and hard (pebble) (Larsonneur et al., 1982), the EUNIS classification (Cabioch et al., 1978)) and biological features such as the distribution of the demerso-benthic community (Vaz et al., 2007) and the main flatfish nursery 
grounds (Riou et al., 2001; Rochette et al., 2010) (Figure 1). In addition, we also explicitly marked out the administrative boundaries represented by the territorial waters of France and of the UK, as well as the coastal areas of these two countries (12 nautical miles from the shore), where different regulations apply (access and gear restrictions, vessel size or horse power limitations) (Figure 1d). To capture these characteristics, the model grid had 35 polygons, with three water column depth layers on the vertical axis $(0-15 \mathrm{~m}, 15-30 \mathrm{~m}$, and $>30 \mathrm{~m}$, the maximal depth of the EEC being $60 \mathrm{~m})$, and a single sediment layer (Figure 2). Two of the polygons were boundary boxes representing the Western English Channel and the Southern North Sea.

\subsubsection{Physical forcing in the Atlantis-EEC model}

Physical exchanges between boxes (advection and diffusion) were computed from outputs of the MARS3D hydrodynamic model (Bailly du Bois and Dumas, 2005). Flows across each face of all the polygons were interpolated using $R$, by allocating each $4 \times 4 \mathrm{~km}$ cell of MARS3D to a particular Atlantis polygon and integrating the flows of all MARS3D cells located at the boundaries of Atlantis polygons. The vertical flows were not available from the MARS3D model outputs, so these were calculated by taking into account both conservation of matter within each cell and the average sea level variation (derived from MARS3D output) in each polygon. The MARS3D outputs used corresponded to the simulation of the year 2006, the most recent non-particular year for which modelled plankton dynamics were validated (Philippe Cugier, pers.com, Ifremer, Plouzané France), continuously looped over the simulation time of 120 years. For consistency with the fluxes, temperature and salinity were forced and nutrient and organic matter concentrations were initialised using the outputs of the MARS3D model averaged over the Atlantis polygons for the same year.

As the EEC is largely influenced by river nutrient flows, notably the Seine on the French side, 16 rivers (nine from France and seven from the UK) were represented in the model (Figure 2). Daily freshwater flows from 2006 were extrapolated from available river gauging station datasets to obtain the flow at the river outlet. Time series of nutrient flows were then calculated from nutrient/flow relationships 
existing for the main rivers (Guillaud, 2008) and inter-polygons fluxes in Atlantis were corrected to account for the amount of water coming from the rivers. Inter-polygons fluxes were standardized to account for hyperdiffusion (due to the compartmentalised structure of space: once in a polygon, any tracer is assumed to be equally accessible throughout the box, which artificially inflates flow), by dividing the fluxes by the distance between centroids of each polygon. A passive tracer (here nitrate) was used to check for any remaining hyperdiffusion.

\subsubsection{Biological functional groups implementation}

Functional groups of species were defined according to similarity of habitat, prey and predator, growth characteristics (mainly maximum size and longevity) and migration patterns. Considering the variety of information available, and its lack of homogeneity, the groups were defined using expert judgment rather than using a clustering method, resulting in 40 functional groups (Table 1). Vertebrates accounted for 21 of those groups, including one seabird and two mammal groups, seven groups of fish species of high commercial interest and eleven other functional groups. 16 groups of invertebrates were also considered, including four plankton groups and seven groups of commercial interest. Finally, detritus was binned into three separate functional groups. Each vertebrate group was further subdivided into 10 age classes of similar width $\left(1 / 10^{\text {th }}\right.$ of the total life span of the group; Table 2). Amongst the invertebrates, cephalopods were represented as stage-structured biomass pools (juveniles and adults), while the other functional groups were considered as single biomass pools.

The initial biomass of each of the 40 groups was derived from a variety of approaches and based on 2002 data. Stock assessment outputs from ICES (International Council for the Exploration of the Sea) were available for six commercial species: sole, plaice, cod (Gadus morhua), whiting (Merlangius merlangus), herring (Clupea harengus) and mackerel (Scomber scombrus) (ICES, 2004, 2005, 2011, 2013a, 2013b) (Table 2). The spatial distribution of sole and plaice stocks is currently assumed to be restricted to ICES Division VIId, so the ICES estimated biomass could be used directly as an input to 
our model. For cod, whiting, herring and mackerel, stock assessments consider areas larger than the EEC, so biomass estimates were reduced using the ratio between the landings over the entire areas versus those from ICES Division VIId. In doing so, we assumed that fishing activity and fish biomass overlapped spatially in the stock areas and that landings were proportional to biomass for each sector. Other sources of information included the Channel Ground Fish Survey (CGFS) (Carpentier et al., 2009), the COMOR Bay of Seine scallops survey (Foucher, 2012), previous EwE models (Carpentier et al., 2009; Daskalov et al., 2011; Mackinson and Daskalov, 2007) and ECOMARS3D outputs for the plankton groups and nutrients (Table 3). The matrix of availability of prey for each predator was derived from the stomach contents database DAPSTOM (http://data.gov.uk/dataset/dapstom, February 2012) and from the EwE models for all the functional groups (Appendix A). Growth rates (parameters of Von Bertalanffy (VB) curve) and length-weight relationships were collected from Fishbase (http://www.fishbase.org/search.php, November 2012) and from the EEC Atlas (Carpentier et al., 2009) (Table 2). To allocate energy to reproduction after maturity, the initial growth rates of mature fish were considered constant and equivalent to the growth rate at first maturity. Using both VB curves and length-weight relationships, the initial weight of each age class for vertebrates functional groups was determined. A Beverton and Holt stock-recruitment (SR) relationship was assumed for all the vertebrates except for mammals and birds for which the amount of offspring per mature individual was assumed constant. The SR curves were either drawn directly from ICES information (http://standardgraphs.ices.dk/stockList.aspx, February 2012) or fitted using available stock assessment data (Table 4). Growth rate and reproduction were considered independent of temperature or salinity, due to the lack of precise information about temperature and salinity optimum in the area studied and also because evaluating the effects of environmental changes was not part of the scope of this study. Biological parameters in functional groups grouping several species were designed by using the average value of the parameters weighted by the initial species biomass. 
Vertebrates, cephalopods and scallops seasonal and spatial distributions were initialised based on existing EEC habitat models (Carpentier et al., 2009), surveys and/or commercial catches. The effects of density-dependence and habitat quality effect were not considered on the spatial distribution of species and their movements, due to a lack of knowledge on these processes, and also because evaluating the effects of habitat degradation was not part of the objectives. Fishes and cephalopods annual spawning as well as the annual migrations of five functional groups (mackerel, whiting, sea bass, herring within the clupeidae and cephalopods), were implemented by setting periods of migration and spawning based on Pawson (1995). The initial distribution of plankton, mammals, seabirds and invertebrates groups except scallops were homogeneous throughout the model domain due to a lack of reliable data.

\subsubsection{Fisheries in Atlantis-EEC model}

Fisheries were explicitly built in our model through a selection of fishing fleets operating a variety of métiers. Both fleets and métiers were defined using the EU DCF (Data Collection Framework) terminology (EC, 2008b). A métier is characterized by the type of gear used and the species or group of species targeted during a fishing operation. A fleet is a group of fishing vessels of similar characteristics (size, power, capacity) and operating the same main métier during the year. Using this typology, 62 fleets could be identified. In this study, we focused on the French fishing fleets targeting sole, which has traditionally been one of the main commercial species in the EEC. This reduced the number of DCF fleets to 20 (essentially netters and dredgers), to which one group was added to include all the other French and foreign vessels operating in the EEC (hereby referred to as the international fleet), making it 21 fleets overall (Table 5).

The main targets of each fleet were assigned based on the catch composition recorded in 2002-2011 logbooks registered by the French Fishery Ministry (DPMA) and extracted from Harmonie, the database of the French Fisheries Information System managed by IFREMER, the French Research Institute for Exploitation of the Sea. 
Partial fishing mortalities per functional groups were applied to represent the impact of the international fishing activities on the ecosystem. They were initialised based on combined 2002 logbook catches, survey indices, and ICES stock abundance. In the case of the French sole fleets on the other hand, series of fishing effort in days at sea were applied for each of them per polygon and quarter. Fishing effort time series were computed from observed values recorded in the Harmonie database, and averaged over 2002-2011. Discards per species were implemented as a proportion of catch per functional groups for each fleet, based on the French at sea observer data (OBSMER program).

The initial fleet catchabilities $(q)$ were derived from 2002 CPUE (catch per unit of effort) per fleets $(f)$ and functional groups (s) relatively to the 2002 biomass of each functional group (equation 1):

$$
\mathrm{q}_{f, s}=\mathrm{CPUE}_{f, s} / \text { Biomass }_{s}
$$

Two different selectivity curves were applied: a normal distribution for netters and a logistic one for the other French sole fleets (Huse et al., 1999, 2000; Madsen et al., 1999; Millar and Fryer, 1999) (Table 5). These curves were fitted using catch-at-length data available over the period 2002-2011 from the OBSMER program.

\subsection{Model calibration}

Although we focus mainly in this paper on the functional groups directly related to plaice and sole in the trophic network of the EEC, more details on Atlantis-EEC calibration relevant to other functional groups may be found in Girardin (2015).

After setting the parameters values based on available literature and data, the model was calibrated to fit the 2002-2011 EEC ecosystem state through four different steps, corresponding to sub-models of increasing complexity. Each step was performed to reduce the risk of error propagation from one 
sub-model to another. The model was run for 80 years in order to stabilize species body size and total population biomass. The modelled ecosystem was considered as stabilized when biological cycles were reproduced and when no major divergences occurred. The model was run 40 more years to evaluate its goodness of fit and account for any remaining divergence.

\subsubsection{Calibration of a simplified NPZD model}

During this first stage of the calibration, only the nutrients, organic matter, and planktonic groups were simulated. We aimed at reproducing the nutrients and plankton temporal dynamics as well as the recycling of organic matter such as they were modelled in ECOMARS3D. Light penetration, sedimentation of nitrogen, hydrodynamic fluxes, and plankton and bacteria parameters were tuned at this step (Table 3).

\subsubsection{Calibration of the ecosystem model}

Once the NPZD calibration was complete, the full ecosystem model was run (i.e. all the functional groups), without running the fishing module. Fishing mortalities of the exploited groups were accounted for through the natural mortality coefficient. The natural mortality of non-commercial functional groups was initialised to 0.3 per year. This step consisted of the calibration of growth, natural mortality, diet and recruitment parameters (Table 4), which were adjusted to achieve outputs with the ecological, physical and chemical processes within an acceptable range, whilst avoiding any erratic behaviour of the model. The final parameter set selected from this tuning process satisfied the following criteria:

(i) individual weight-at-age of vertebrates within $20 \%$ of their initial values throughout the duration of the run;

(ii) average biomass of each functional group between the minimum and the maximum of biomass reported in the literature, assessments or surveys between 2002 and 2011, and

(iii) natural (non-predation) mortality maintained at as low a level as possible. 


\subsubsection{Calibration with explicit forcing fishing pressure using time series of catches}

Once the biophysical model reflected the average observed biomass, the fishing mortality component of the total mortality coefficient was removed and instead fishing activities were included explicitly through the 20 French fleets targeting sole plus the international fleet. Daily spatialized time series of catch per functional groups and polygons were used to force catches of the 20 French fleets targeting sole; these were calculated from landings data averaged over 2002-2011.

Biological parameters and the international fishing mortality rate (Tables 3 and 4) were tuned to adjust vertebrate biomasses in the range of assessment or survey estimations over 2002-2011 and catches of the international fleet similar to the observed catches (http://www.ices.dk/marinedata/dataset-collections/Pages/Fish-catch-and-stock-assessment.aspx, September 2014) over the same period.

\subsubsection{Calibration with spatially resolved fishing effort}

In this last step, series of fishing effort were applied instead of the catch time series to represent the activity of the French fleets fishing for sole (Girardin, 2015). Catchability values (Appendix B) were adjusted from their initial values such that the catches modelled during the first year of run matched the average catches per species realised for each sole fleet for the period 2002-2011. Then growth rates and recruitment were slightly adjusted to keep functional groups biomass in the range of 20022011 observed data (Table 2 and 4). Finally, catchability and fishing mortality were adjusted for the catch of the fleets remaining out of the acceptable range defined previously.

During this four-step calibration process, we attempted to avoid changing the value of the parameters tuned during the previous step. However, additional adjustments were necessary to take into account new interactions and indirect effects. We focused here on calibrating a base scenario that captured the dynamics of the EEC ecosystem between 2002 and 2011. We aimed at: 
(i) keeping the biomass of vertebrate functional groups biomass between the maximum and the minimum biomass observed in assessment and surveys and also,

(ii) maintaining the catches by fleet within $+/-20 \%$ of the observed average for each functional group during that period.

\subsection{Analyses of model outputs}

To evaluate the goodness of fit of our model, the average outputs from Atlantis-EEC simulation over the years 80 to 120 were compared (i.e. average of 40 years following the spin up period) with average observed data over the period 2002-2011. First, the ratio between the catch outputs of Atlantis-EEC and the total observed catches was investigated (i.e. landings and discards when available) for each combination of fleet and métier (Figure 3). Then, the overall Atlantis biomass of any surveyed or assessed vertebrates was compared with the range of biomass estimates available from assessments and CGFS surveys between 2002 and 2011 (Figure 4).

One of the key components of ecosystem models is the representation of the trophic network structure. Both predation mortality and biomass of the functional groups after 100 years of the calibration run were considered to analyse the complex interactions between each of them. The trophic network of vertebrates (Figure 5) and the network around sole and plaice are presented in two ways. First, the proportional contribution per predator to the predation mortality of each prey (Figure 5a and 6a) is explored, and then the relative importance of prey functional groups in diet of predator (Figure $5 b$ and $6 b$ ) is investigated.

The different functional groups were ranked by deriving their trophic level from the simulation outputs (Figure 6). Each trophic level was derived from mortality per predation and biomass of each functional group outputs.

Finally, the three types of mortality used in Atlantis: predation mortality, natural mortality other than predation (resulting from calibration), and fishing mortality were analysed. Then Atlantis fishing 
mortalities were compared with those derived from ICES single- and multi-species stock assessments (Figure 7).

\section{Results}

We report here, (i) the general lessons drawn from the calibration process, (ii) how well the outputs of our Atlantis model adhere to existing catch and biomass information available from logbook, survey and stock assessment results, (iii) the main findings concerning the structure and functioning of the EEC food web and finally, (iv) a comparison of the mortalities estimated across a selection of models including Atlantis-EEC for key EEC species.

\subsection{Learning from the calibration process}

The calibration process has involved an extended set of iterations between the comparison of model output to data and the identification of parameters and/or processes that needed to be considered for tuning or modification. At the beginning of the calibration, the model was run without explicit river inputs. Then, in each coastal polygon, nutrients and detrital matter, as well as the main benthic invertebrates and the recruitment of the nursery-dependent functional groups, especially flatfish, decreased quickly. During the adjustment of the detrital matter availability and benthic invertebrates biological parameters, especially the deposit feeders groups, most vertebrates did not grow well when the availability of benthic groups was too low. Moreover, fishing activities were first included without discards. When discards were introduced in the model, the benthic biomass increased, and an increase in the growth and biomass of vertebrates was observed (which then had to be recalibrated to maintain both biomass and average length of these groups within observation range).

\subsection{Evaluation of the calibration on catch data}

The standard error around the average Atlantis catch was small, and most of the fleets were within the $+/-20 \%$ of average observed data that was considered as acceptable (Figure 3, Appendix C). The 
main exceptions to this were clupeids, small gadoids and demersal fishes, for which most of the fleets catches were out of acceptable range, as well as rays and dogfishes, crabs, lobsters, bivalves and scallops, for which few fleets catches (1-4 out of 21) were poorly modelled (Appendix C). Cod catches were well represented by Atlantis-EEC, despite a slight tendency to underestimate catches $(<12 \%)$ for most trammel net métiers (FC11, FC13 and FC16) and to overestimate those of all other métiers $(<10 \%)$, compared to the 2002-2011 average. Whiting and sole catches were best represented with a catch overestimation lower than $6 \%$ for all métiers. Finally, although modelled plaice catches of all fleets were in the $+/-20 \%$ acceptability range, the difference with the observed average catch was somehow more important (up to 16\%). Fleets using others métiers (FC5 and FC20) and the international fleet (FC21) overestimated the plaice catches. To the contrary, trammel nets métier (FC4, FC11, FC13, FC16 and FC19) underestimated plaice catches. Amongst these fleets, trammel netters of length $<10 \mathrm{~m}$ to $18 \mathrm{~m}$, dredgers of length $10-12 \mathrm{~m}$ operating other métiers (FC5) and the international fleet (FC21) importantly contributed to the plaice catches.

\subsection{Comparison of total biomass estimated by Atlantis (calibration run), single-species stock} assessments and surveys

The biomass of each functional group was relatively stable, although slightly more variable in the case of whiting (Figure 4). The biomasses of cod, whiting, sole and plaice from our model were comprised between the maximum and minimum of stock assessment estimates, over the period 2002-2011. Cod, whiting and sole biomasses, with respectively an average of 12,000 tons, 110,000 tons and 19,000 tons simulated by the model, were in the upper bound of the stock assessment estimation while conversely plaice was in the lower bound with an average simulated biomass of 7300 tons. Of the other groups that are not subject to an ICES stock assessment, only rays/dogfishes and shark biomasses were in the range of CGFS biomass indices between 2002 and 2011. Biomasses output from Atlantic-EEC of seabass, dab, sparidae, gurnards and other flatfishes were higher than estimates from survey data (Figure 4). 


\subsection{Analysis of interactions within the trophic network}

Whiting, cod, rays, sharks and large bottom fishes were the main contributors to vertebrate mortality (Figure 5a). Whiting and cod impacted more than eight functional groups. Cod was the most important predator of sole and plaice, while whiting represented more than $25 \%$ of sole predation mortality. In contrast, neither plaice nor sole fed on vertebrate groups. The groups "Clupeidae" (over $30 \%$ of mackerels, seabirds, whiting, rays and others flatfishes diets), "mackerel and horse mackerel" (over $30 \%$ of cetacean, sharks, large bottom fish and seabirds diets), and "small demersal fishes" (over $30 \%$ of seabass (Dicentrarchus labrax), sparidae and plaice diets) were the three main forage functional groups consumed by predators (Figure 5b). The model suggested that whiting was important both as a predator and as a prey in the EEC ecosystem. The importance of cannibalism for some functional groups such as cod, whiting, sharks, rays, other flatfishes and large bottom fishes is highlighted (Figure 5).

Plaice and sole mainly foraged on lower level preys such as deposit feeders, bivalves and scallops for sole and small demersal fishes and crabs for plaice (Figure 6b). Plaice and sole mainly competed for food with crabs. Plaice also competed with small demersal fishes and whiting, but to a lesser extent. Crabs were also one of the main source of food for rays/dogfishes and cephalopods. Sole was the only predator of scallops. As could be expected from the general patterns reported above, sole and plaice represented only a small proportion of their predator diet and were only significant in the diet of cod, rays and large bottom fishes (Figure 6b). Three other groups represented a large proportion of the top predator diet: whiting for rays, large bottom fishes for cod, cod and large bottom fishes for seals. However, when considering the importance of predators to the predation mortality of sole and plaice, cod was clearly the main predator of both species. Rays, whiting and seals also contributed somewhat to sole predation mortality (Figure 6a). Regarding the other groups in this sub-network, whiting considerably impacted Clupeidae and small demersal fishes, cod contributed significantly to 
the mortality of large bottom fishes and whiting, and seals, representing the highest top predator of this trophic network, impacted mainly cod, large bottom fishes, sole and plaice.

\subsection{Importance of fishing mortality on the target groups.}

For plaice, sole and cod, the mortality due to predation did not exceed 0.05 year $^{-1}$ and represented a small part of the total mortality compared to the fishing mortality, which was around 0.18 year $^{-1}$ for sole, 0.13 year $^{-1}$ for cod, and 0.38 year $^{-1}$ for plaice (Figure 7). Whiting was the only group that was more impacted by predation mortality $\left(0.39\right.$ year $\left.^{-1}\right)$ than by fishing mortality $\left(0.1\right.$ year $\left.^{-1}\right)$. Our model estimated a smaller fishing mortality for cod, whiting, plaice and sole compared to single-species stock assessments output. However, Atlantis-EEC outputs were closest to the fishing mortality resulting from the multi-species assessment for cod and whiting.

\section{Discussion}

The interest in ecosystem-based management has grown during the past four decades (Arkema et al., 2006; Brodziak and Link, 2002; FAO, 2003; Sanchirico et al., 2006). This development has been supported by considerable improvement of the scientific knowledge around marine ecosystem functioning and increased computing performance, which have favoured the development of several end-to-end models building in comprehensive ecosystem dynamics (Fulton et al., 2011b; Plagányi, 2007).

The development of Atlantis-EEC aimed at synthetizing current knowledge on the EEC ecosystem. The dynamics of the ecosystem captured sought to emulate the 2002-2011 observations. During the calibration process, key drivers of the EEC ecosystem dynamics were highlighted, and knowledge in the calibration of the Atlantis model improved.

\subsection{Knowledge on the Eastern English Channel ecosystem dynamics}

The salient features are summarized here. The implementation of river inputs in Atlantis-EEC increased the productivity of benthic invertebrates and then improved the recruitment of nursery- 
dependent functional groups, especially sole and plaice. These results bear out the crucial importance of estuaries on the nurseries productivity (Kostecki et al., 2010; Le Pape et al., 2013; Riou et al., 2001; Rochette et al., 2010).

In Atlantis-EEC, the dynamics of benthic invertebrates and the recycling of detrital matter were essential to the functioning of the entire ecosystem. This feature had also been revealed in the English Channel EwE application (Carpentier et al., 2009; Daskalov et al., 2011), the model outputs of which were particularly sensitive to the mortality of benthic groups. In the EEC, most of the species are highly linked to the benthos (Carpentier et al., 2009; Dauvin and Desroy, 2005). The diet of demersal functional groups is mainly composed of benthic invertebrates (Cachera, 2013) and the deposit feeder functional groups represent a key component of our model.

Discards increased the productivity of benthic invertebrates, especially deposit feeders that improved the growth and recruitment of demersal fish. This highlights the relative importance of discards in the trophic network, as had already been observed in earlier studies, suggesting for example that discarded blue whiting (Micromesistius poutassou) impacted the diet of lesser spotted dogfish (Scyliorhinus canicula) (Olaso et al., 1998). There is then a dual effect of fishing activities on the ecosystem: a pressure exerted on blue whiting abundance, and a source of food resulting from discards for other ecosystem components, e.g., lesser spotted dogfish. In the EU, a landing obligation is being implemented as part of the Common Fisheries Policy (CFP) (EC, 2013). Our results highlight how all aspects of the CFP landing obligation need to be carefully considered by decision-makers since this management measure will not only have direct impacts on fishing fleets and fisheries but may also have indirect effects on the whole ecosystem, and indirectly, on the entire fishery systems.

In our model, cod and whiting emerged as keystone species in the food web of the EEC. Any modification of the biological parameters of these groups impacted the dynamics of the entire ecosystem. For instance, increasing the biomass of those groups considerably decreased the biomass of the other prey or predator groups. Similar patterns of importance of these gadoids were observed 
during the calibration of another ecosystem model, OSMOSE, applied to the EEC (Morgane TraversTrolet, pers. com., Ifremer, Boulogne-sur-Mer France). In contrast, plaice and sole had a limited impact on other vertebrates groups, but were strongly dependent on the productivity of nursery grounds and on the availability of benthic invertebrates, which bears out the outcomes of previous studies (Dauvin and Desroy, 2005; Kostecki et al., 2010; Le Pape et al., 2013; Riou et al., 2001; Rochette et al., 2010).

\subsection{Model performance}

Atlantis-EEC was calibrated to fit observed catches per fleet and per métier. The catches of the focused species for all of the fleets were reproduced within the $+/-20 \%$ acceptability range. However, within this range, in the case of cod and plaice, catches for fleets that do not usually target those species were underestimated (trammel netters) or overestimated (other métiers) with at least $8 \%$ of difference with average observed catches. Indeed, for these fleets, fitting the catches proved more challenging due to the paucity of data available to estimate catchability and/or selectivity. This is particularly true for netters, which use trammel nets when targeting sole. In the absence of better information on that gear in the EEC, the selectivity of trammel nets was modelled using a normal distribution, based on an analysis of existing at-sea observers catch and length frequency data. Using this selectivity curve in Atlantis-EEC results in netters mainly targeting fish of the first and second age classes. First attempt to fit netters cod catches resulted in an increase of cod juveniles catchability, a sharp decrease of cod juveniles abundance, and eventually a collapse of the cod population after a few years. The netters cod catchability was then reduced and the cod natural mortality (other than predation) was increased to counterbalance the low adult fishing mortality from netters, the representation of missing predation on juveniles and the likely migration to the North Sea. As is often the case with end-to-end models, it was not possible to perfectly mimic all the observed variables due to complex interactions between species, size-classes and the various fleets represented. The 
calibration undertaken aimed at correctly representing the dynamics of the main targeted flatfish species and their related fleets.

The calibrated model represents the biomass of assessed species within the range of the 2002-2011 average stock assessment (ICES, 2013a). A difference between Atlantis biomass and CGFS surveyderived biomass indices was observed (Figure 6), which can be explained by several reasons: (i) the biomass derived from CGFS has to be corrected in order to take into account the selectivity of the gear used (Table 5), but correction cannot be done for all species due to lack of data, (ii) the CGFS survey occurs in October while biomass simulated by Atlantis are annual estimates, with substantial differences for migratory species in particular, (iii) interactions within species and with simulated fleets can make the calibration of biomass difficult due to non-linear dynamics of the system.

Finally, Atlantis-EEC produces estimates of the mortality resulting from both fishing and predation that can be compared with estimates from other sources (Figure 7). The comparison with singlespecies stock assessment results was only indicative, since only fishing mortality is calculated in single-species evaluations, while natural mortality is kept constant over time for sole and plaice $\left(\mathrm{M}=0.1\right.$ year $^{-1}$ for sole and plaice) and derived from SMS for cod and whiting ( $M=0.4$ year $^{-1}$ for cod, 0.7 year $^{-1}$ for whiting). It is still instructive that the main source of mortality for cod, sole and plaice is fishing activities, as observed in the assessment (ICES, 2013a). For whiting, however, predation and fishing have an equivalent contribution to the total mortality. In the whiting assessment, fishing mortality reference points are poorly estimated, which could be due to an underestimation of predation mortality that could be alleviated by applying a multi-species stock assessment model for this stock (ICES, 2013a; Lewy and Vinther, 2004). Cod and whiting fishing mortalities output from both Atlantis and multispecies stock assessment are lower than the fishing mortality derived from single-species stock assessments (Figure 7).

\subsection{The calibration process: what has been learned about the behaviour of the model?}


The development of the Atlantis-EEC did not only improve our knowledge of the EEC ecosystem functioning, it also provided further insights into the behaviour of the model that could help future applications, consistent with the conclusions of Link et al. (2010) (Pinnegar et al., submitted).

Atlantis can be implemented with any spatial structure. The definition of the polygons comes first, and it is one of the most important steps in the model development. In this study, at first, 38 polygons were implemented, which had to be reduced to correct some issues with the biogeochemical dynamics sub-model. The nutrients in some of the smallest polygons were vented too quickly, while other polygons acted as sinks for nutrients due to local eddies occurring near the estuary of the Seine (polygon 20) and in the Bay of Veys (polygon 17) (Figure 2). To deal with these issues the geometry was simplified and the over-accumulation of nutrients was corrected by including the river plume during the creation of the hydrodynamics file.

The second step was to choose the structure of the functional groups. Vertebrates can be split into several age classes, with each age class representing a part of the group life cycle and ranging from one to five years. In the EEC Atlantis, the calibration of the groups biological and fisheries parameters became more complex as the number of years per age class increased. When implementing fishing effort and gear selectivity, the assumption of homogeneity within each age class was an issue for groups with more than two years per age class. It complicated the calibration of biomass, length and catch per age class of sole and plaice. For instance, initially, four years per age class for plaice and three for sole were implemented but had to be reduced to two years per age class for both species. This was due to the average size of fish in the first age class being too high otherwise, so all the juveniles were available to fishing too quickly which led to steep biomass decreases.

The choice of the reproduction model also proved decisive during the calibration. Reproduction was built in through two processes: (i) a constant number of offspring for mammals, seabirds, rays and sharks and (ii) a stock recruitment relationship for the other vertebrates. A Beverton and Holt stockrecruitment relation was applied, which was best documented in the fisheries literature. The use of a 
Ricker formulation implies the consideration of density dependency in the reproduction process, which would be in conflict with other parameters such as cannibalism in the diet matrix or the quadratic mortality that already considered density dependencies. In the quasi-absence of very large natural predator (or explicit density dependent controls on the highest trophic levels), the calibration of the top predator natural mortality was highly uncertain. This proved particularly problematic for rays and sharks which ultimately had to be modelled with reproduction represented as a stock recruitment relationship to stabilize the biomass of these populations.

To stabilize catch and biomass to recent average levels for each functional group, several parameters had to be modified simultaneously. The calibration thus allowed us to gain a good understanding of the key parameters driving the modelled EEC ecosystem dynamics (Fulton, 2001), focusing first on the growth to achieve a sensible vertebrates length size, then adjusting the natural mortality if necessary, and finally the reproduction parameters.

\subsection{Perspectives}

Further development of Atlantis-EEC could be considered to improve our understanding of the EEC ecosystem. For example, simulation of the hydrodynamics with MARS3D could be performed over 2002-2011 to match with the calibration period used. Rather than reproducing the average EEC ecosystem behaviour over 2002-2011, the calibration could be done to mimic each year of the time series of catches and biomasses between 2002 and 2011. The development of Atlantis-EEC also highlighted the necessity to improve our knowledge on data-limited species, especially benthic communities, which seemed to be one of the key drivers of the EEC ecosystem. The development of the fishery sub-model, including the introduction of fleet dynamics in Atlantis-EEC, would also be an indispensable prerequisite to evaluate the impact of management scenarii on the ecosystem (e.g., fishing area closures or effort reduction).

An analysis of uncertainty and/or sensitivity of the model would have highlighted the key uncertain parameters for which a refined tuning would be necessary. An important step forward would hence 
be to identify and analyse the main sources of uncertainty in our model. Due to the numerous parameters considered in Atlantis, the application of sensitivity/uncertainty propagation analyses would require using, (i) meta-models (Grace et al., 2010), (ii) experimental plans to reduce the number of simulations based on, e.g., the Morris methods (Lehuta et al., 2013; Morris, 1991), Latin Hypercube Sampling (LHS, Gasche et al., 2013; Helton and Davis, 2003; McKay et al., 1979), (iii) sobol indices (Sobol', 2001), to explore the uncertainty in our application or, (iv) other techniques such as adaptive screening already tested on Atlantis (Pantus, 2007).

Another way to analyse the strength and weakness of our application would be to compare the outcomes of our model with those from other EEC ecosystem models, when evaluating the same scenarios. In addition to the EwE (Daskalov et al., 2011) and the Atlantis-EEC (this study), two other spatially-explicit models are currently being developed for the EEC. An application of the OSMOSE ecosystem model (Travers-Trolet, 2012) has thus recently been developed and integrates the spatial and temporal dynamics of a set of age- and length-structured vertebrate and cephalopod groups, as well as their trophic interactions. The other mixed-species model of the area is ISIS-Fish (Lehuta et al., 2015), which focuses on the spatial dynamics of some targeted fish species and the fisheries exploiting them, and which makes explicit prevision for mixed fisheries dynamics. ISIS-Fish is divided into three sub-models, the fishery, the biology and management. Trophic interactions, however, are not explicitly considered in this model (Mahévas and Pelletier, 2004). A logical future step would then be to compare the outcomes of all the ecosystem models of the region. Such a comparison would provide insights into how robust our understanding of ecosystem dynamics is (i.e. where do the models agree or differ), and would identify the strengths and weaknesses of the various models in relation to the scientific questions they address.

\section{Conclusions}


The development of the Atlantis-EEC application improved our knowledge of the functioning of the EEC ecosystem. Despite knowledge gaps for some parameter estimates, it was possible, after several steps of calibration, to successfully reproduce the salient processes and dynamics of the ecosystem. Two main species, cod and whiting, were highlighted as key opportunistic predator components of that ecosystem, as well as the benthic invertebrates groups, which provide food for most of the upper trophic levels groups. While sole and plaice were found to be less important in the upper trophic network, they were found to be highly dependent on benthos, of which they are important predators.

From the implementation of the fishery in the model, three key observations emerged: (i) the relative prominence of the fishing mortality (compared to other sources of mortality) for cod, plaice and sole, (ii) the necessity of applying a multispecies approach to assessing the impact of fishing (with the example of whiting) and, (iii) the importance of discarding in the trophic network.

This model application, which includes some representation of the entire marine ecosystem, represents our best (current) understanding of the Eastern English Channel.

\section{Acknowledgements}

This study was funded by the European Community's Seventh Framework Programme (FP7/20072013) under Grant Agreement No. 266445 for the project VECTORS of Change in Oceans and Seas Marine Life, Impact on Economic Sectors (VECTORS). Additional funding and resources from the IFREMER PhD grant system, as well as support from the Wealth from Ocean Flagship and CSIRO Marine and Atmospheric Research, are also gratefully acknowledged. We are also indebted to the thorough comments two anonymous reviewers and the editor, which greatly improved the manuscript. 


\section{References}

Ainsworth, C.H., Morzaria-Luna, H., Kaplan, I.C., Levin, P.S., Fulton, E.A., Cudney-Bueno, R., TurkBoyer, P., Torre, J., Danemann, G.D., and Pfister, T. (2012). Effective ecosystem-based management must encourage regulatory compliance: A Gulf of California case study. Mar. Policy 36, 1275-1283.

Arkema, K.K., Abramson, S.C., and Dewsbury, B.M. (2006). Marine ecosystem-based management: from characterization to implementation. Front. Ecol. Environ. 4, 525-532.

Auber, A., Travers-Trolet, M., Villanueva, M.C., and Ernande, B. (2015). Regime shift in an exploited fish community related to natural climate oscillations. PLoS ONE 10, e0129883.

Bailly du Bois, P., and Dumas, F. (2005). Fast hydrodynamic model for medium- and long-term dispersion in seawater in the English Channel and southern North Sea, qualitative and quantitative validation by radionuclide tracers. Ocean Model. 9, 169-210.

Batsleer, J., Poos, J.J., Marchal, P., Vermard, Y., and Rijnsdorp, A.D. (2013). Mixed fisheries management: protecting the weakest link. Mar. Ecol. Prog. Ser. 479, 177-190.

Beaugrand, G., Ibanez, F., and Reid, P.C. (2000). Spatial, seasonal and long-term fluctuations of plankton in relation to hydroclimatic features in the English Channel, Celtic Sea and Bay of Biscay. Mar. Ecol. Prog. Ser. 200, 93-102.

Botsford, L.W., Castilla, J.C., and Peterson, C.H. (1997). The management of fisheries and marine ecosystems. Science 277, 509-515.

Brodziak, J., and Link, J.S. (2002). Ecosystem-based fishery management: What is it and how can we do it? Bull. Mar. Sci. 70, 589-611.

Browman, H.I., and Stergiou, K.I. (2004). Perspectives on ecosystem-based approaches to the management of marine resources. Mar. Ecol. Prog. Ser. 274, 269-303.

Cabioch, L., and Glaçon, R. (1975). Distribution des peuplements benthiques en Manche Orientale, de la Baie de Somme au Pas-de-Calais. C R Acad Sci Paris 280 D, 491-494.

Cabioch, L., Gentil, F., Glaçon, R., and Rétière, C. (1978). Cartographie des peuplements macrobenthiques en Manche orientale. Prod. Numér. REBENT Ifremer-Univ.-CNRS 2007.

Cachera, M. (2013). Implications of morphological and functional traits for trophic relationships within fish and marine trophic network architecture. Université Science et Technologies de Lille, 2013. English. 225.

Carpentier, A., Coppin, F., Curet, L., Dauvin, J.-C., Delavenne, J., Dewarumez, J.-M., Dupuis, L., Foveau, A., Garcia, C., Gardel, L., et al. (2009). Channel Habitat Atlas for marine Ressource Management, final report / Atlas des Habitats des Ressources Marines de la Manche Orientale, rapport final (Charm phase II). INTERREG 3a Programme IFREMER Boulogne-Sur-Mer Fr. 626.

Christensen, V., and Walters, C.J. (2004). Ecopath with Ecosim: methods, capabilities and limitations. Ecol. Model. 172, 109-139. 
Cugier, P., Billen, G., Guillaud, J.F., Garnier, J., and Ménesguen, A. (2005). Modelling the eutrophication of the Seine Bight (France) under historical, present and future riverine nutrient loading. J. Hydrol. 304, 381-396.

Daskalov, G.M., Mackinson, S., and Mulligan, B. (2011). Modelling possible food-web effects of aggregate dredging in the Eastern English Channel, Final Report. Mar. Aggreg. Levy Sustain. Fund MEPF 08/P37, 65.

Dauvin, J.-C., and Desroy, N. (2005). The food web in the lower part of the Seine estuary: a synthesis of existing knowledge. Hydrobiologia 540, 13-27.

Daw, T., and Gray, T. (2005). Fisheries science and sustainability in international policy: a study of failure in the European Union's Common Fisheries Policy. Mar. Policy 29, 189-197.

Delavenne, J., Metcalfe, K., Smith, R.J., Vaz, S., Martin, C.S., Dupuis, L., Coppin, F., and Carpentier, A. (2012). Systematic conservation planning in the eastern English Channel: comparing the Marxan and zonation decision-support tools. ICES J. Mar. Sci. J. Cons. 69, 75-83.

EC (2008a). Directive 2008/56/EC of the european parliament and of the council of 17 June 2008 establishing a framework for community action in the field of marine environmental policy (Marine Strategy Framework Directive). Off. J. Eur. Union 22.

EC (2008b). Commission decision of 6 november 2008 adopting a multiannual community programme pursuant to council regulation (EC) No 199/2008 establishing a community framework for the collection, management and use of data in the fisheries sector and support for scientific advice regarding the common fisheries policy (2008/949/EC). Off. J. Eur. Union 52.

EC (2013). Regulation (EU) No 1380/2013 of the European parliament and of the council of 11 december 2013 on the Common Fisheries Policy, amending council regulations (EC) No 2371/2002 and (EC) No 639/2004 and council decision 2004/585/EC.

Ellien, C., Thiebaut, E., Barnay, A., Dauvin, J., Gentil, F., and Salomon, J. (2000). The influence of variability in larval dispersal on the dynamics of a marine metapopulation in the eastern Channel. Oceanol. Acta 23, 423-442.

Ellis, J. R., and Rogers, S. I. (2000). The distribution, relative abundance and diversity of echinoderms in the eastern English Channel, Bristol Channel, and Irish Sea. J. Mar. Biol. Assoc. U. K. 80, 127-138.

FAO (2003). Fisheries management - 2. The ecosystem approach to fisheries. Rome FAO 112.

Foucher, E. (2012). Evaluation annuelle du stock de coquilles Saint-Jacques de la baie de Seine : résultats de la campagne COMOR 42. Rapport IFREMER, décembre 2012. 14.

Fulton, E.A. (2001). The effects of model structure and complexity on the behaviour and performance of marine ecosystem models. PhD thesis, School of Zoology, University of Tasmania, Hobart, Australia. $427 \mathrm{pp}$.

Fulton, E.A. (2010). Approaches to end-to-end ecosystem models. J. Mar. Syst. 81, 171-183.

Fulton, E.A., Fuller, M., Smith, A.D.M., and Punt, A.E. (2005). Ecological indicators of the ecosystem effects of fishing : final report. (Hobart : Canberra: CSIRO ; Australian Fisheries Management Authority). 
Fulton, E.A., Smith, A.D.M., and Smith, D.C. (2007). Alternative management strategies for Southeast Australian Commonwealth fisheries: Stage 2: Quantitative management strategy evaluation (Australia: CSIRO ; Australian Fisheries Management Authority).

Fulton, E.A., Smith, A.D.M., Smith, D.C., and van Putten, I.E. (2011a). Human behaviour: the key source of uncertainty in fisheries management. Fish Fish. 12, 2-17.

Fulton, E.A., Link, J.S., Kaplan, I.C., Savina-Rolland, M., Johnson, P., Ainsworth, C., Horne, P., Gorton, R., Gamble, R.J., Smith, A.D.M., et al. (2011b). Lessons in modelling and management of marine ecosystems: the Atlantis experience. Fish Fish. 12, 171-188.

Garcia, S.M. (1994). The precautionary principle: its implications in capture fisheries management. Ocean Coast. Manag. 22, 99-125.

Garcia, C., Chardy, P., Dewarumez, J.-M., and Dauvin, J.-C. (2011). Assessment of benthic ecosystem functioning through trophic web modelling: the example of the eastern basin of the English Channel and the Southern Bight of the North Sea. Mar. Ecol. 32, 72-86.

Garcia, S.M., Zerbi, A., Aliaume, C., Do Chi, T., and Lasserre, G. (2003). The ecosystem approach to fisheries: issues, terminology, principles, institutional foundations, implementation and outlook. Rome FAO 71.

Gasche, L., Mahévas, S., and Marchal, P. (2013). Supporting fisheries management by means of complex models: Can we point out isles of robustness in a sea of uncertainty? PLoS ONE 8, e77566.

Girardin, R. (2015). Ecosystem and fishers' behaviour modelling: two crucial and interacting approaches to support ecosystem based fisheries management in the Eastern English Channel. Université Lille 1, 2015. English.

Girardin, R., Vermard, Y., Thébaud, O., Tidd, A., and Marchal, P. (2015). Predicting fisher response to competition for space and resources in a mixed demersal fishery. Ocean Coast. Manag. 106, 124135.

Grace, J.B., Anderson, T.M., Olff, H., and Scheiner, S.M. (2010). On the specification of structural equation models for ecological systems. Ecol. Monogr. 80, 67-87.

Guillaud, J.F. (2008). Calcul en temps réel des concentrations fluviales en nutriments, en fonction des débits, sur la façade Atlantique, la Manche et le sud de la Mer du Nord. Rapport IFREMER, septembre 2008 - RST.DYNECO Pélagos 08-05.

Helton, J.C., and Davis, F.J. (2003). Latin hypercube sampling and the propagation of uncertainty in analyses of complex systems. Reliab. Eng. Syst. Saf. 81, 23-69.

Hilborn, R. (2004). Ecosystem-based fisheries management: the carrot or the stick? Mar. Ecol. Prog. Ser. 274, 275-278.

Hilborn, R., Maguire, J.-J., Parma, A.M., and Rosenberg, A.A. (2001). The precautionary approach and risk management: can they increase the probability of successes in fishery management? Can. J. Fish. Aquat. Sci. 58, 99-107.

Huse, I., C. Gundersen, A., and H. Nedreaas, K. (1999). Relative selectivity of Greenland halibut (Reinhardtius hippoglossoides, Walbaum) by trawls, longlines and gillnets. Fish. Res. 44, 75-93. 
Huse, I., Løkkeborg, S., and Soldal, A.V. (2000). Relative selectivity in trawl, longline and gillnet fisheries for cod and haddock. ICES J. Mar. Sci. J. Cons. 57, 1271-1282.

ICES (2004). Report of the working group on the assessment of mackerel, horse mackerel, sardine and anchovy (WGMHSA), 9-18 September 2003, ICES Headquarters, Copenhagen. ICES CM 2004/ACFM:08, $493 \mathrm{pp}$.

ICES (2005). Report of the study group on sea bass (SGBASS), 9-18 September 2003, ICES Headquarters, Copenhagen. ICES CM 60pp.

ICES (2011). Report of the working group on multispecies assessment methods (WGSAM), 10-14 October 2011, Woods Hole, USA. ICES CM 2011/SSGSUE:10., 229 pp.

ICES (2013a). Report of the working group on the assessment of demersal stocks in the North Sea and Skagerrak (WGNSSK), 24 - 30 April 2013, ICES Headquarters, Copenhagen. ICES CM 2013/ACOM:13., 1435 pp.

ICES (2013b). Report of the herring assessment working group for the area South of $62 \mathrm{~N}$ (HAWG), 12-21 March 2013, ICES Headquarters, Copenhagen. ICES CM 2013/ACOM:06., 1270 pp.

ICES (2014). Interim report of the working group on multispecies assessment methods (WGSAM), 2024 October 2014, London, UK. ICES CM 2014/SSGSUE:11, 104 pp.

Kaplan, I.C., Horne, P.J., and Levin, P.S. (2012). Screening California Current fishery management scenarios using the Atlantis end-to-end ecosystem model. Prog. Oceanogr. 102, 5-18.

Kishi, M.J., Ito, S., Megrey, B.A., Rose, K.A., and Werner, F.E. (2011). A review of the NEMURO and NEMURO.FISH models and their application to marine ecosystem investigations. J. Oceanogr. 67, 316.

Korotenko, K., Sentchev, A., Schmitt, F.G., and Jouanneau, N. (2013). Variability of turbulent quantities in the tidal bottom boundary layer: Case study in the eastern English Channel. Cont. Shelf Res. 58, 21-31.

Kostecki, C., Le Loc'h, F., Roussel, J.-M., Desroy, N., Huteau, D., Riera, P., Le Bris, H., and Le Pape, O. (2010). Dynamics of an estuarine nursery ground: the spatio-temporal relationship between the river flow and the food web of the juvenile common sole (Solea solea, L.) as revealed by stable isotopes analysis. J. Sea Res. 64, 54-60.

Larsonneur, C., Bouysse, P., and Auffret, J.-P. (1982). The superficial sediments of the English Channel and its Western approaches. Sedimentology 29, 851-864.

Lehodey, P., Senina, I., and Murtugudde, R. (2008). A spatial ecosystem and populations dynamics model (SEAPODYM) - Modeling of tuna and tuna-like populations. Prog. Oceanogr. 78, 304-318.

Lehuta, S., Mahévas, S., Le Floc'h, P., and Petitgas, P. (2013). A simulation-based approach to assess sensitivity and robustness of fisheries management indicators for the pelagic fishery in the Bay of Biscay. Can. J. Fish. Aquat. Sci. 70, 1741-1756.

Lehuta, S., Vermard, Y., and Marchal, P. (2015). A spatial model of the mixed demersal fisheries in the Eastern Channel. In Marine Productivity: Perturbations and Resilience of Socio-Ecosystems, H.-J. Ceccaldi, Y. Hénocque, Y. Koike, T. Komatsu, G. Stora, and M.-H. Tusseau-Vuillemin, eds. (Springer International Publishing), pp. 187-195. 
Le Pape, O., Modéran, J., Beaunée, G., Riera, P., Nicolas, D., Savoye, N., Harmelin-Vivien, M., Darnaude, A.M., Brind'Amour, A., Le Bris, H., et al. (2013). Sources of organic matter for flatfish juveniles in coastal and estuarine nursery grounds: A meta-analysis for the common sole (Solea solea) in contrasted systems of Western Europe. J. Sea Res. 75, 85-95.

Leslie, H.M., and McLeod, K.L. (2007). Confronting the challenges of implementing marine ecosystem-based management. Front. Ecol. Environ. 5, 540-548.

Lewy, P., and Vinther, M. (2004). A stochastic age-length structured multi-species model applied to North Sea stocks.

Link, J.S., Fulton, E.A., and Gamble, R.J. (2010). The northeast US application of ATLANTIS: A full system model exploring marine ecosystem dynamics in a living marine resource management context. Prog. Oceanogr. 87, 214-234.

Ludwig, D. (2002). A Quantitative Precautionary Approach. Bull. Mar. Sci. 70, 485-497.

Mackinson, S., and Daskalov, G. (2007). An ecosystem model of the North Sea to support an ecosystem approach to fisheries management: description and parametrisation. Sci. Ser. Tech. Rep. Cefas Lowestoft 142, 196.

Madsen, N., Holst, R., Wileman, D., and Moth-Poulsen, T. (1999). Size selectivity of sole gill nets fished in the North Sea. Fish. Res. 44, 59-73.

Mahévas, S., and Pelletier, D. (2004). ISIS-Fish, a generic and spatially explicit simulation tool for evaluating the impact of management measures on fisheries dynamics. Ecol. Model. 171, 65-84.

Marchal, P., Gasche, L., Girardin, R., Pape, O.L., Huret, M., Mahévas, S., Travers-Trolet, M., and Vaz, S. (2015). From data to end-to-end models: 15 years of research to describe the dynamics of exploited marine ecosystems in the Eastern Channel. In Marine Productivity: Perturbations and Resilience of Socio-Ecosystems, H.-J. Ceccaldi, Y. Hénocque, Y. Koike, T. Komatsu, G. Stora, and M.-H. TusseauVuillemin, eds. (Springer International Publishing), pp. 169-173.

Maury, O., Faugeras, B., Shin, Y.-J., Poggiale, J.-C., Ari, T.B., and Marsac, F. (2007). Modeling environmental effects on the size-structured energy flow through marine ecosystems. Part 1: The model. Prog. Oceanogr. 74, 479-499.

McAllister, M., and Kirchner, C. (2002). Accounting for structural uncertainty to facilitate precautionary fishery management: illustration with Namibian orange roughy. Bull. Mar. Sci. 70, 499-540.

McKay, M.D., Beckman, R.J., and Conover, W.J. (1979). A comparison of three methods for selecting values of input variables in the analysis of output from a computer code. Technometrics 21, 239-245.

Millar, R.B., and Fryer, R.J. (1999). Estimating the size-selection curves of towed gears, traps, nets and hooks. Rev. Fish Biol. Fish. 9, 89-116.

Morris, M.D. (1991). Factorial sampling plans for preliminary computational experiments. Technometrics 33, 161-174.

Olaso, I., Velasco, F., and Pérez, N. (1998). Importance of discarded blue whiting (Micromesistius poutassou) in the diet of lesser spotted dogfish (Scyliorhinus canicula) in the Cantabrian Sea. ICES J. Mar. Sci. J. Cons. 55, 331-341. 
Pantus, F.J. (2007). Sensitivity analysis for complex ecosystem models. PhD Thesis Sch. Phys. Sci. Univ. Qld.

Pawson, M.G. (1995). Biogeographical identification of English Channel fish and shellfish stocks. Fisheries Research Technical Report, MAFF Direct. Fish. Res., Lowestoft, (99). 72pp.

Pikitch, E.K., Santora, C., Babcock, E.A., Bakun, A., Bonfil, R., Conover, D.O., Dayton, P., Doukakis, P., Fluharty, D., Heneman, B., et al. (2004). Ecosystem-based fishery management. Science 305, 346347.

Pinnegar, J., Sinerchia, M., Palacz, A., Hufnagl, M., Girardin, R., Peck, M.A., and Rasmus, J. (submitted). Application of the holistic modelling framework ATLANTIS to European Shelf Seas: lessons learnt and continuing challenges. Estuar. Coast. Shelf Sci.

Plagányi, É.E. (2007). Models for an ecosystem approah to fisheries. FAO Fish. Tech. Pap. No. 477. Rome, FAO. 2007, $108 \mathrm{p}$.

van Putten, I.E., Kulmala, S., Thébaud, O., Dowling, N., Hamon, K.G., Hutton, T., and Pascoe, S. (2012). Theories and behavioural drivers underlying fleet dynamics models. Fish Fish. 13, 216-235.

Riou, P., Le Pape, O., and Rogers, S.I. (2001). Relative contributions of different sole and plaice nurseries to the adult population in the Eastern Channel: application of a combined method using generalized linear models and a geographic information system. Aquat. Living Resour. 14, 125-135.

Rochette, S., Rivot, E., Morin, J., Mackinson, S., Riou, P., and Le Pape, O. (2010). Effect of nursery habitat degradation on flatfish population: Application to Solea solea in the Eastern Channel (Western Europe). J. Sea Res. 64, 34-44.

Rosenberg, A.A. (2002). The precautionary approach in application from a manager's perspective. Bull. Mar. Sci. 70, 577-588.

Sanchirico, J.N., Smith, M.D., and Lipton, D.W. (2006). An approach to ecosystem-based fishery management. Resour. Future Discuss. Pap.

Savina, M., and Ménesguen, A. (2008). A deterministic population dynamics model to study the distribution of a benthic bivalve with planktonic larvae (Paphia rhomboïdes) in the English Channel (NW Europe). J. Mar. Syst. 70, 63-76.

Savina, M., Forrest, R.E., Fulton, E.A., and Condie, S.A. (2013). Ecological effects of trawling fisheries on the eastern Australian continental shelf: a modelling study. Mar. Freshw. Res. 64, 1068-1086.

Shin, Y.-J., and Cury, P. (2001). Exploring fish community dynamics through size-dependent trophic interactions using a spatialized individual-based model. Aquat. Living Resour. 14, 65-80.

Shin, Y.-J., and Cury, P. (2004). Using an individual-based model of fish assemblages to study the response of size spectra to changes in fishing. Can. J. Fish. Aquat. Sci. 61, 414-431.

Sinclair, M., and Valdimarsson, G. (2003). Responsible fisheries in the marine ecosystem. FAO Rome CABI Publ. Wallingford UK.

Sobol', I.M. (2001). Global sensitivity indices for nonlinear mathematical models and their Monte Carlo estimates. Math. Comput. Simul. 55, 271-280. 
Tidd, A.N., Vermard, Y., Marchal, P., Pinnegar, J., Blanchard, J.L., and Milner-Gulland, E.J. (2015). Fishing for space: fine-scale multi-sector maritime activities influence fisher location choice. PLoS ONE 10, e0116335.

Travers, M., Shin, Y.-J., Jennings, S., and Cury, P. (2007). Towards end-to-end models for investigating the effects of climate and fishing in marine ecosystems. Prog. Oceanogr. 75, 751-770.

Travers, M., Shin, Y.-J., Jennings, S., Machu, E., Huggett, J.A., Field, J.G., and Cury, P.M. (2009). Twoway coupling versus one-way forcing of plankton and fish models to predict ecosystem changes in the Benguela. Ecol. Model. 220, 3089-3099.

Travers-Trolet, M. (2012). End-to-end model of the eastern English Channel food web-Final report of EU program Interreg 4A Charm 3, Action 11.3.

Ulrich, C., Le Gallic, B., and Dunn, M.R. (1999). Bioeconomic modelling of English Channel fisheries and their technical interactions: presentation of the simulation model BECHAMEL (BioEconomic CHAnnel ModEL). ICES CM 4.

Vanhoutte-Brunier, A., Fernand, L., Ménesguen, A., Lyons, S., Gohin, F., and Cugier, P. (2008). Modelling the Karenia mikimotoi bloom that occurred in the western English Channel during summer 2003. Ecol. Model. 210, 351-376.

Vaz, S., Carpentier, A., and Coppin, F. (2007). Eastern English Channel fish assemblages: measuring the structuring effect of habitats on distinct sub-communities. ICES J. Mar. Sci. J. Cons. 64, 271-287.

Wilen, J.E., Smith, M.D., Lockwood, D., and Botsford, L.W. (2002). Avoiding surprises: Incorporating fisherman behavior into management models. Bull. Mar. Sci. 70, 553-575. 
Figure captions :

Figure 1 : Biogeography and administrative boundaries in the Eastern English Channel. The maps represent a) the distribution of sediments grouped in five separate categories defined by Larsonneur et al. (1982); b) the main nursery grounds of the main commercial species (Carpentier et al., 2009); c) the distribution of the biosediment EUNIS typology; and d) the boundaries of the VIId ICES Division, the French and UK Exclusive Economic Zones and the 12 miles coastal waters zone.

Figure 2 : Spatial structure of the Atlantis application in the Eastern English Channel. The number of layers are shown with different colours, yellow for one layer $(<15 \mathrm{~m})$, green for two $(<30 \mathrm{~m})$ and blue for three $(<60 \mathrm{~m})$. Red dots represent the position of river estuaries. The river names are indicated for reference.

Figure 3 : Estimation of the performance of the model, considering sole, plaice, cod and whiting catches output from Atlantis over years 80 to 120. Catches of each combination of fleet and métier forecast by Atlantis are compared to landing and discard data over 2002-2011. The Y-axis represents the ratio between output and observed data. The X-axis represents the codes of the different combinations of fleets and métiers, which have been ranked in increasing order of their landing weights cumulated over all species. The green line represents an exact match, and the black dotted lines represent the range of acceptance (i.e. $20 \%$ around that level). The red dots represent the ratios between forecast and observations, and the black segment their standard error.

Figure 4 : Comparison of Atlantis biomasses between years 80 and 120 of the calibration period and biomasses assessed or observed during the CGFS survey. The Y-axis represents the biomass in tons and the X-axis represents the different species considered. Red dots represent the average biomasses of each species during the period considered in Atlantis with their standard error (black segment). The blue bars represent the maximum and minimum biomasses assessed by the ICES over 2002-2011 and the orange bars represent the same limits applied to CGFS survey data over the same time period.

Figure 5 : Overall structure of the modelled trophic relationships. The rows of this matrix represent the predators and the columns the prey: a) proportion of mortality per predation for each prey; b) proportion of each prey in the predators' diet. A shade of blue is used to characterize the intensity of each proportion.

Figure 6 : Trophic networks around sole and plaice, a) proportion of the prey in the predator diet; b) proportion of predation mortality due to a predator. The recalculated trophic level is represented on the $\mathrm{Y}$-axis. The 
thickness of arrows represents the intensity of the trophic relation between two species. The size of each hexagon represents the biomass of each functional group. We represented in red seals, in blue piscivorous groups, in light blue non-piscivorous fish, in orange crabs, in grey filter feeders, in brown deposit feeders and in pink flatfish species.

Figure 7 : Cod, plaice sole and whiting mortalities output from Atlantis between simulation years 80-120. The red bar represents fishing mortality $(\mathrm{F})$, the blue bar the predation mortality $(\mathrm{Mp})$, and the green bar the natural (other than predation or fishing) mortality (Mn). Fishing mortalities derived from ICES single-species ( $\left.F_{\text {WGNSSK }}\right)$ and multispecies $\left(F_{\text {SMS }}\right)$ stock assessments are represented as black triangles and black dots, respectively. 
Table 1: Description of functional groups species composition in Atlantis Eastern English Channel application. Focus functional groups and key functional groups are underlined.

\begin{tabular}{|c|c|c|}
\hline Code & Group & Species \\
\hline SB & Seabirds & $\begin{array}{l}\text { fulmar (Fulmarus glacialis), Manx shearwater (Puffinus puffinus), storm petrel (Hydrobates pelagicus), gannet (Sula bassana), } \\
\text { cormorant (Phalacrocorax carbo), gulls (Larus melanocephalus, Larus ridibundus, Larus canus, Larus fuscus, Larus argentatus, } \\
\text { and Larus marinus), kittiwake (Rissa tridactyla), terns (Sterna sandvicensis, Sterna dougalli, Sterna hirundo, Sterna paradisaea, } \\
\text { and Sterna albifrons), guillemot (Uria aalge), razor bill (Alca torda) and puffin (Fratercula arctica) }\end{array}$ \\
\hline CET & Toothed cetaceans & $\begin{array}{l}\text { Harbour porpoise (Phocoena phocoena), common dolphin (Delphinus delphis) and longfinned pilot whale (Globicephala } \\
\text { melas). }\end{array}$ \\
\hline SXX & Seals & Grey seals (Halichoerus grypus) and harbour seals (Phoca vitulina) \\
\hline$\underline{\mathrm{COD}}$ & Cod & North Atlantic cod (Gadus morhua) \\
\hline SHK & Sharks & $\begin{array}{l}\text { tope (Galeorhinus galeus), porbeagle (Lamna nasus), blue shark (Prionace glauca), starry smooth-hound (Mustelus asterias), } \\
\text { smooth-hound (Mustelus mustelus) and thintail thresher (Alopias vulpinus) }\end{array}$ \\
\hline CEP & Cephalopods & veined squid (Loligo forbesii), European squid (Loligo vulgaris) and common cuttlefish (Sepia officinalis) \\
\hline WHG & Whiting & Whiting (Merlangius merlangius) \\
\hline$\overline{\mathrm{PLE}}$ & Plaice & European plaice (Pleuronectes platessa) \\
\hline$\overline{\mathrm{DAB}}$ & $\overline{\mathrm{Dab}}$ & common dab (Limanda Limanda) \\
\hline OFF & Other flatfishes & $\begin{array}{l}\text { lemon sole (Microstomus kitt), megrim (Lepidorhombus whiffiagonis), topknot (Zeugopterus punctatus), turbot (Psetta } \\
\text { maxima), brill (Scophthalmus rhombus), European flounder (Platichthys flesus), Sand sole (Pegusa lascaris), Thickback sole } \\
\text { (Microchirus variegatus), Solenette (Buglossidium luteum), scaldfish (Arnoglossus sp.) }\end{array}$ \\
\hline MAC & Mackerels & North-east Atlantic mackerel (Scomber scombrus) and horse mackerel (Trachurus trachurus) \\
\hline CLU & Clupeidae & Atlantic herring (Clupea harengus), European sprat (Sprattus sprattus) and European pilchard (Sardina pilchardus) \\
\hline SPA & Sparidae & $\begin{array}{l}\text { blackspot seabream (Pagellus bogaraveo),Common pandora (Pagellus erythrinius), gilthead seabream (Sparus auratus) and } \\
\text { black bream (Spondyliosoma cantharus). }\end{array}$ \\
\hline
\end{tabular}




\section{Table 1 (continued)}

\begin{tabular}{|c|c|c|}
\hline Code & Group & Species \\
\hline GUX & Gurnards & $\begin{array}{l}\text { red gurnard (Chelidonichthys cuculus), tub gurnard (Chelidonichthys lucerna) and grey gurnard (Chelidonichthys } \\
\text { gurnardus) }\end{array}$ \\
\hline MUL & Mugilidae & $\begin{array}{l}\text { thinlip mullet (Liza ramada), golden grey mullet (Liza aurata), thicklip grey mullet (Chelon labrosus) and striped red } \\
\text { mullet (Mullus surmuletus). }\end{array}$ \\
\hline GAD & Other Gadoids & pouting (Trisopterus luscus), and poor cod (Trisopterus minutus) \\
\hline SMD & Small demersal fishes & $\begin{array}{l}\text { sand goby (Pomatoschistus minutus), hooknose (Agonus cataphractus), dragonet (Callionymus maculates), rokling fish, } \\
\text { Greater weever (Trachinus draco), lesser weever (Enchiichthys vipera), Blenniidae and sandeels (Ammodytes tobianus, } \\
\text { Ammodytes marinus). }\end{array}$ \\
\hline LBE & Lobsters & European lobster (Homarus gammarus)and spiny lobster (Palinurus elephas) \\
\hline CRA & Crabs & $\begin{array}{l}\text { shore crab (Carcinus maenas), common hermit crab (Pagurus bernhardus), hairy crab (Pilumnus hirtellus) ,velvet } \\
\text { swimming crab (Necora puber), edible crab (Cancer pagurus), and spider crab (Maja squinado) }\end{array}$ \\
\hline SHP & Shrimps & common prawn (Palaemon serratus), brown shrimp (Crangon crangon), Norway lobster (Nephrops norvegicus) \\
\hline WHE & Whelks & common whelk (Buccinum undatum) $\quad$ Y \\
\hline SUS & Suspension feeder & Benthic cnidarians, sponges, bryozoans and ascidians \\
\hline DEP & Deposit feeder & polychaeta and amphipods \\
\hline SCE & Scallops & common scallops (Pecten maximus), and queen scallops (Chlamys opercularis) \\
\hline BIV & Bivalves & $\begin{array}{l}\text { cockles (Cerastoderma edule), softshelled clam (Mya arenaria), blue mussels (Mytilus edulis), and oysters (Ostrea edulis } \\
\text { and Crassostrea gigas) }\end{array}$ \\
\hline $\mathrm{ECH}$ & Echinoderm & $\begin{array}{l}\text { Asterias rubens, Astropecten irregularis, Spatangus purpureus, Psammechinus miliaris, Echinus esculentus, Solaster } \\
\text { endeca, Ophiura ophiura, Crossaster papposus, Echinocarsium cordatum and Ophiothrix fragilis }\end{array}$ \\
\hline ZOO & Zooplankton & \\
\hline ZOC & Carnivorous zooplankton & \\
\hline ZOG & Gelatinous zooplankton & \\
\hline PP & Phytoplankton & \\
\hline BB & Benthic bacteria & \\
\hline PB & Pelagic bacteria & \\
\hline $\mathrm{DL}$ & Labile detrital & \\
\hline DR & Refractory detrital & \\
\hline DET & Carrion/Discard & \\
\hline
\end{tabular}


Table 2: Initial biomass, age class structure and growth rate per class and length-weight relationship for vertebrates in the Atlantis Eastern English Channel application, after calibration. Biomass † from EwE (Carpentier et al., 2009), * from CGFS survey, \# from assessment (ICES, 2004, 2013a, 2013b)

\begin{tabular}{|c|c|c|c|c|c|c|c|c|c|c|c|c|c|c|}
\hline \multirow[t]{2}{*}{ specie } & \multicolumn{2}{|c|}{ Initial condition } & \multicolumn{10}{|c|}{ Growth per class (mg N. d-1) } & \multicolumn{2}{|c|}{ Length/weight } \\
\hline & $\begin{array}{c}\text { Biomass } \\
\text { (tons) }\end{array}$ & $\begin{array}{l}\text { age } \\
\text { per } \\
\text { class }\end{array}$ & 1 & 2 & 3 & 4 & 5 & 6 & 7 & 8 & 9 & 10 & $a$ & $\mathbf{b}$ \\
\hline SB & $70.6+$ & 4 & 4000 & 34000 & 9000 & 9000 & 9000 & 9000 & 9000 & 9000 & 9000 & 9000 & 0.02 & 3 \\
\hline CET & $125.5^{\dagger}$ & 8 & $910^{5}$ & $310^{5}$ & $710^{4}$ & $710^{4}$ & $710^{4}$ & $710^{4}$ & $710^{4}$ & $710^{4}$ & $710^{4}$ & $710^{4}$ & 0.01 & 3 \\
\hline SXX & $6.6+$ & 5 & $410^{5}$ & $1.210^{5}$ & $1.310^{4}$ & $1.310^{4}$ & $1.310^{4}$ & $1.310^{4}$ & $1.310^{4}$ & $1.310^{4}$ & $1.310^{4}$ & $1.310^{4}$ & 0.035 & 2.9 \\
\hline COD & 15 041\# & 2 & 34.52 & 54.52 & 320 & 320 & 400 & 460 & 460 & 460 & & 460 & 0.00835 & 3.0532 \\
\hline RAY & & 2 & 36.6 & 6.61 & 02.92 & 124.81 & 14 & 140.81 & 140.81 & 140.81 & 81 & & 048 & 783 \\
\hline SHK & & 5 & 7092.8 & 7046.1 & 7046.1 & 7046.1 & 7046.1 & 7046.1 & 7046.1 & 7046.1 & 7046.1 & & 73 & 533 \\
\hline WHG & 199\# & 2 & .45 & 67.13 & 65. & 70.13 & 70.13 & 60.13 & 50.13 & 50.13 & 50. & 50 & 0.00 & 28 \\
\hline $\mathrm{POL}$ & $92+$ & 2 & .80 & 120.9 & 150 & 200 & & 400 & 400 & 400 & 0 & 40 & 0.00 & 3.1153 \\
\hline LBT & $12603+$ & 3 & 150.51 & 363.39 & 802.93 & 2153.9 & 2159.2 & 2260.2 & 2360.2 & 2360.2 & 2360.2 & 2360.2 & 0.03328 & 2.7659 \\
\hline BSS & & 2 & & & & 131.37 & & & 181.37 & 181.37 & & & & 529 \\
\hline SOL & & 2 & & & & 16.17 & & & 13.17 & 13.17 & & & & 3.2639 \\
\hline PLE & & 2 & 50.57 & 110.44 & 221.44 & 221.44 & 221.44 & 221.44 & 221.44 & 221.44 & 221.44 & 221.44 & & 3.0169 \\
\hline DAB & & 1 & 0.88 & & 5.90 & 5.90 & 5.90 & & 7.90 & 7.90 & 7.5 & 7.5 & 47 & 3.2211 \\
\hline OFF & & 2 & & & & 7.49 & 7.49 & 7.49 & 8.49 & 8.49 & 8. & 8.49 & & 3.0514 \\
\hline MAC & 87 530\# & 2 & 8.90 & 10.25 & 19.25 & 19.25 & 19.25 & 19.25 & 19.25 & 19.25 & 19.25 & 19.25 & 0.00338 & 3.1085 \\
\hline CLU & $\begin{array}{c}516 \\
240 \#+\end{array}$ & 1 & 3 & 1.3 & 1.3 & 1.3 & 1.3 & 1.3 & 1.3 & 1.3 & 1.3 & 1.3 & 0.00564 & 3.0576 \\
\hline SPA & $6965^{\dagger}$ & 2 & 6.07 & 14.45 & 42.29 & 42.29 & & 42.29 & 42.29 & 42.29 & 42.29 & & & 3.1414 \\
\hline GUX & $15588^{+}$ & 2 & 2.16 & 12.17 & 12.17 & 12.17 & 15.17 & 15.17 & 13.17 & 13.17 & 13.17 & 13.17 & 0.00528 & 3.1407 \\
\hline MUL & $82915^{\dagger}$ & 1 & 4.35 & 6.06 & 15.81 & 17.26 & 19.44 & 19.42 & 19.42 & 19.42 & 19.42 & 19.42 & 0.00756 & 3.0574 \\
\hline GAD & $126030+$ & 1 & 10.13 & 12.61 & 15.61 & 15.61 & 15.61 & 15.61 & 15.61 & 15.61 & 15.61 & 15.61 & 0.00728 & 3.1333 \\
\hline SMD & $199360^{\dagger}$ & 1 & 0.15 & 0.15 & 0.15 & 0.15 & 0.15 & 0.15 & 0.15 & 0.15 & 0.15 & 0.15 & 0.0123 & 2.8092 \\
\hline
\end{tabular}


Table 3: Initial Biomass and biological parameters of invertebrates in the Atlantis Eastern English Channel application, after calibration. Biomass + from EwE (Carpentier et al., 2009), * from COMOR survey (Foucher, 2012) and \# from ECOMARS3D.

\begin{tabular}{|c|c|c|c|c|c|}
\hline \multirow[t]{2}{*}{ species } & \multirow{2}{*}{$\begin{array}{c}\begin{array}{c}\text { Initial } \\
\text { condition }\end{array} \\
\text { Biomass } \\
\text { (tons) }\end{array}$} & \multirow{2}{*}{$\begin{array}{c}\text { Growth } \\
\text { (mg N } \\
\text { d-1) }\end{array}$} & \multicolumn{3}{|c|}{ Mortality (d-1) } \\
\hline & & & linear & quadratic & fishing \\
\hline CEP & $3130+$ & 0.007 & 0 & 0 & 0.0012 \\
\hline LBE & $439+$ & 0.0023 & $1.668110^{-4}$ & 0.0044 & $5.6110^{-5}$ \\
\hline CRA & $425014+$ & 0.0006 & 0 & $1.610^{-6}$ & $1.06110^{-5}$ \\
\hline SHP & $391101 \dagger$ & 0.002 & $2.107110^{-5}$ & $410^{-4}$ & $1.20910^{-6}$ \\
\hline WHE & $8338+$ & 0.0016 & 0 & $410^{-4}$ & $9.010^{-5}$ \\
\hline SUS & $171154+$ & 0.04 & 0 & $210^{-6}$ & 0 \\
\hline DEP & $829146+$ & 0.04 & 0 & $2.510^{-6}$ & 0 \\
\hline SCE & $379854^{*}$ & 0.0475 & $7.459310^{-4}$ & $3.510^{-6}$ & $2.45810^{-5}$ \\
\hline BIV & $675162+$ & 0.05 & 0 & $510^{-6}$ & $5.5210^{-6}$ \\
\hline $\mathrm{ECH}$ & $296396+$ & 0.0017 & 0.0001 & $210^{-5}$ & 0 \\
\hline ZOO & 19802\# & 0.17 & 0.005 & $1.410^{-3}$ & 0 \\
\hline ZOC & 15132\# & 0.037 & 0.0005 & $7.510^{-4}$ & 0 \\
\hline ZOG & $840+$ & 0.02 & 0.0005 & 0.009 & 0 \\
\hline $\mathrm{PP}$ & 297 015\# & 1 & 0.1 & 0 & 0 \\
\hline BB & 90\# & 1.5 & 0.1 & 0 & 0 \\
\hline PB & 13 823\# & 1.2 & 0.8 & 0 & 0 \\
\hline
\end{tabular}


Table 4: Reproduction and mortality parameters for vertebrates in the Atlantis Eastern English Channel application, after calibration. Two reproduction relationships are used: a Beverton and Holt stock recruitment curve (BH), or a number of recruits per adult. Only the fishing mortality induced by the international fleet is shown.

\begin{tabular}{|c|c|c|c|c|c|c|c|}
\hline \multirow[t]{3}{*}{ species } & \multicolumn{4}{|c|}{ Reproduction } & \multicolumn{3}{|c|}{ Mortalities $\left(d^{-1}\right)\left(10^{-6}\right)$} \\
\hline & \multirow{2}{*}{$\begin{array}{c}\text { class at } \\
\text { first } \\
\text { maturity }\end{array}$} & \multirow{2}{*}{$\begin{array}{l}\text { BH } \alpha \\
\left(10^{9}\right)\end{array}$} & \multirow{2}{*}{$\begin{array}{l}\text { BH } \beta \\
\left(10^{6}\right)\end{array}$} & \multirow{2}{*}{$\begin{array}{l}\text { \# per } \\
\text { adult }\end{array}$} & \multicolumn{2}{|c|}{ natural linear } & \multirow[t]{2}{*}{ fishing } \\
\hline & & & & & juvenile & adult & \\
\hline SB & 2 & & & 0.28 & 500.0 & 100.0 & 0 \\
\hline CET & 2 & & & 0.5 & 970.0 & 0.1 & 0 \\
\hline SXX & 2 & & & 0.5 & 800.0 & 50.0 & 0 \\
\hline COD & 2 & 0.046 & 3.09 & & 40.0 & 6.584 & 149.174 \\
\hline RAY & 2 & 0.182 & 4.00 & & 200.0 & 22.703 & 419.198 \\
\hline SHK & 2 & 0.0205 & 0.1 & & 0.1 & 0 & 1626.163 \\
\hline WHG & 2 & 22.502 & 46.7 & & 0 & 0 & 449.957 \\
\hline POL & 2 & 0.0141 & 4.16 & & 200.0 & 548.11 & 61.11 \\
\hline LBT & 2 & 0.0062 & 6.00 & & 100.0 & 228.77 & 48.74 \\
\hline BSS & 3 & 0.0630 & 0.30 & & 8.0 & 0 & 371.129 \\
\hline SOL & 2 & 0.346 & 3.72 & & 0 & 0 & 129.021 \\
\hline PLE & 2 & 0.186 & 3.50 & & 0 & 0 & 928.794 \\
\hline DAB & 3 & 2.900 & 10.0 & & 0 & 0.02154 & 235.179 \\
\hline OFF & 2 & 0.205 & 10.0 & & 4.0 & 2.5674 & 69.31 \\
\hline MAC & 2 & 8.063 & 20.0 & & 0 & 0.05 & 275.569 \\
\hline CLU & 2 & 40693 & 3.00 & & 0.02 & 0 & 7311.472 \\
\hline SPA & 2 & 0.774 & 0.35 & & 40.0 & 442.2 & 502.175 \\
\hline GUX & 2 & 0.226 & 6.00 & & 20.0 & 240.76 & 307.476 \\
\hline MUL & 2 & 2.838 & 45.0 & & 250.0 & 840.48 & 32.76 \\
\hline GAD & 2 & 251.765 & 30.0 & & 0 & 0 & 110.301 \\
\hline SMD & 2 & 11555 & 3.00 & & 0 & 0 & 14.63 \\
\hline
\end{tabular}


Table 5: Description of Atlantis Eastern English Channel combinations of DCF fleets and métiers, with their implementation, selectivity curves type and their parameters values.

\begin{tabular}{|c|c|c|c|c|c|c|c|c|}
\hline Index & Code & DCF fleets & DCF métiers & Implementation & Selectivity & $\alpha(\mathrm{cm})$ & $\beta$ & Main species \\
\hline FC1 & fl26dredSCE & dredgers $10-12 \mathrm{~m}$ & dredge on scallops & Spatial effort & Logistic & 10.0 & 2.3 & SCE \\
\hline $\mathrm{FC2}$ & fl26otbMUL & dredgers $10-12 \mathrm{~m}$ & $\begin{array}{l}\text { bottom trawl on } \\
\text { demersal fish }\end{array}$ & Spatial effort & Logistic & 16.2 & 0.48 & PLE, CEP \\
\hline FC3 & fl26tbbSOL & dredgers $10-12 \mathrm{~m}$ & $\begin{array}{l}\text { beam trawl on } \\
\text { demersal fish }\end{array}$ & Spatial effort & Logistic & 16.5 & 0.9 & SOL, PLE, OFF \\
\hline FC4 & fl26netSOL & dredgers $10-12 \mathrm{~m}$ & trammel nets & Spatial effort & Normal & 25.5 & 5.6 & SOL \\
\hline FC5 & fl26othLBT & dredgers $10-12 \mathrm{~m}$ & others & Spatial effort & Logistic & 45.0 & 0.26 & PLE, MAC \\
\hline FC6 & fl27dredSCE & dredgers $12-18 \mathrm{~m}$ & dredge on scallops & Spatial effort & Logistic & 9.0 & 2.3 & SCE \\
\hline $\mathrm{FC7}$ & fl27otbCOD & dredgers $12-18 \mathrm{~m}$ & $\begin{array}{l}\text { bottom trawl on } \\
\text { demersal fish }\end{array}$ & Spatial effort & Logistic & 17.5 & 0.3 & CEP, MAC, RAY \\
\hline FC8 & fl27otbCEP & dredgers $12-18 \mathrm{~m}$ & $\begin{array}{l}\text { bottom trawl on } \\
\text { cephalopods }\end{array}$ & Spatial effort & Logistic & 10.0 & 0.4 & CEP, RAY \\
\hline FC9 & fl27tbbRAY & dredgers $12-18 \mathrm{~m}$ & $\begin{array}{l}\text { beam trawl on } \\
\text { demersal fish }\end{array}$ & Spatial effort & Logistic & 8.5 & 1.2 & RAY, SOL, PLE \\
\hline FC10 & $\mathrm{fl} 27 \mathrm{midwcCLU}$ & dredgers $12-18 \mathrm{~m}$ & $\begin{array}{l}\text { mid water otter } \\
\text { trawl on pelagic fish }\end{array}$ & Spatial effort & Logistic & 15.5 & 0.3 & MAC, CLU \\
\hline FC11 & fl27netSOL & dredgers $12-18 \mathrm{~m}$ & trammel nets & Spatial effort & Normal & 25.5 & 5.6 & SOL, PLE, OFF \\
\hline FC12 & fl27othWHE & dredgers $12-18 \mathrm{~m}$ & others & Spatial effort & Logistic & 16.5 & 0.5 & PLE, MAC, CRA \\
\hline FC13 & fl43netSOL & Passive gears <10m & trammel nets & Spatial effort & Normal & 25.5 & 5.6 & SOL, PLE, RAY \\
\hline FC14 & fl43othWHE & Passive gears <10m & others & Spatial effort & Logistic & 23.5 & 2.3 & CEP, BSS, WHE \\
\hline FC15 & fl44dredSCE & Passive gears $10-12 \mathrm{~m}$ & dredge on scallops & Spatial effort & Logistic & 8.5 & 2.3 & SCE \\
\hline FC16 & fl44netSOL & Passive gears $10-12 \mathrm{~m}$ & trammel nets & Spatial effort & Normal & 28.0 & 3.5 & SOL, PLE, RAY \\
\hline FC17 & fl44othWHE & Passive gears $10-12 \mathrm{~m}$ & others & Spatial effort & Logistic & 35.0 & 0.12 & RAY, MAC, WHE \\
\hline FC18 & fl49dredSCE & Trammel netters $12-18 \mathrm{~m}$ & dredge on scallops & Spatial effort & Logistic & 8.8 & 2.0 & SCE \\
\hline FC19 & fl49netSOL & Trammel netters $12-18 \mathrm{~m}$ & trammel nets & Spatial effort & Normal & 30.0 & 5.6 & SOL, PLE, RAY \\
\hline FC20 & fl49othCEP & Trammel netters $12-18 \mathrm{~m}$ & others & Spatial effort & Logistic & 35.0 & 0.12 & SOL,PLE, COD \\
\hline FC21 & IntOTH & International fleets & & $\begin{array}{l}\text { Fishing } \\
\text { mortality }\end{array}$ & none & & & \\
\hline
\end{tabular}


1)

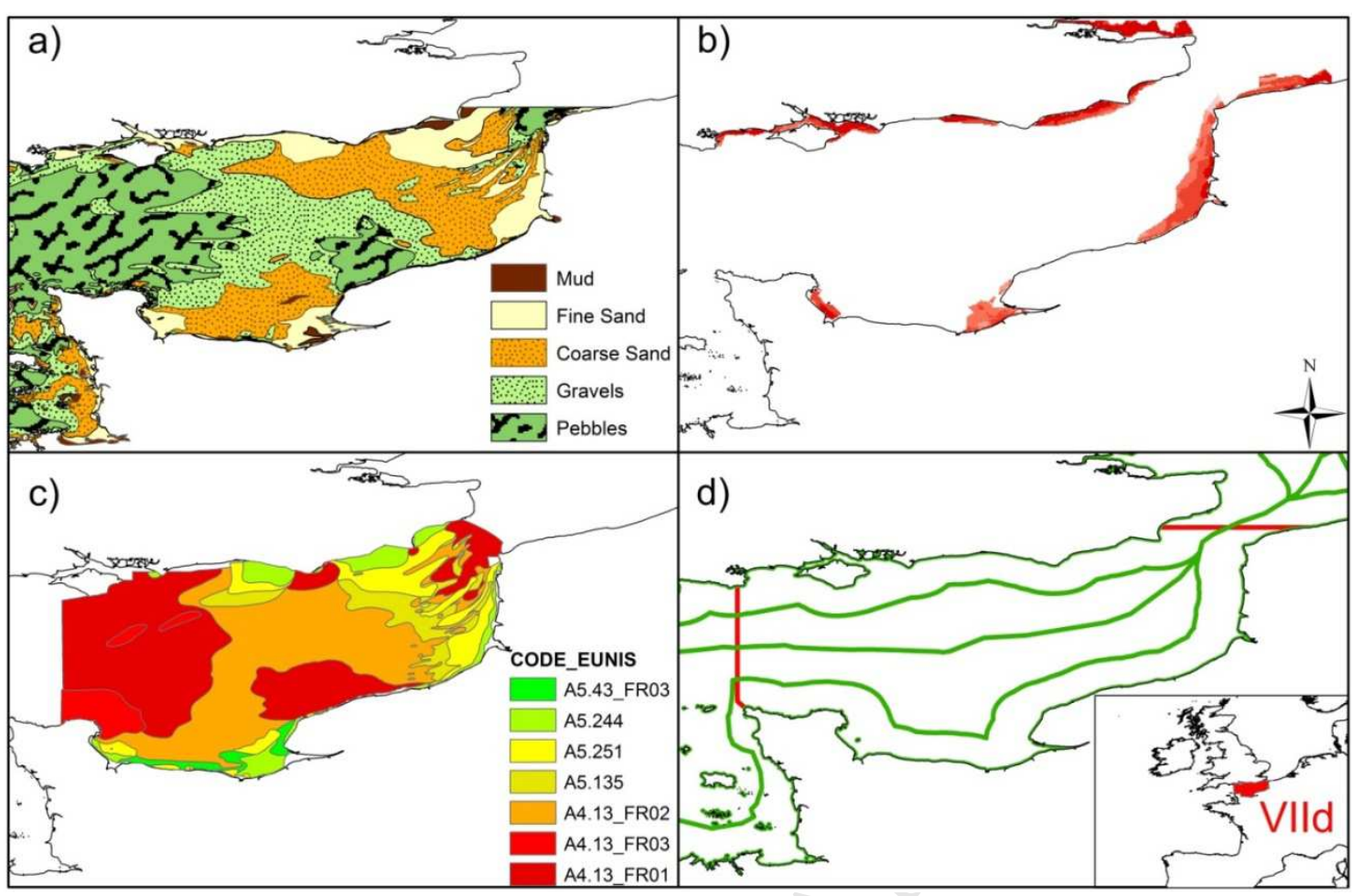

2)

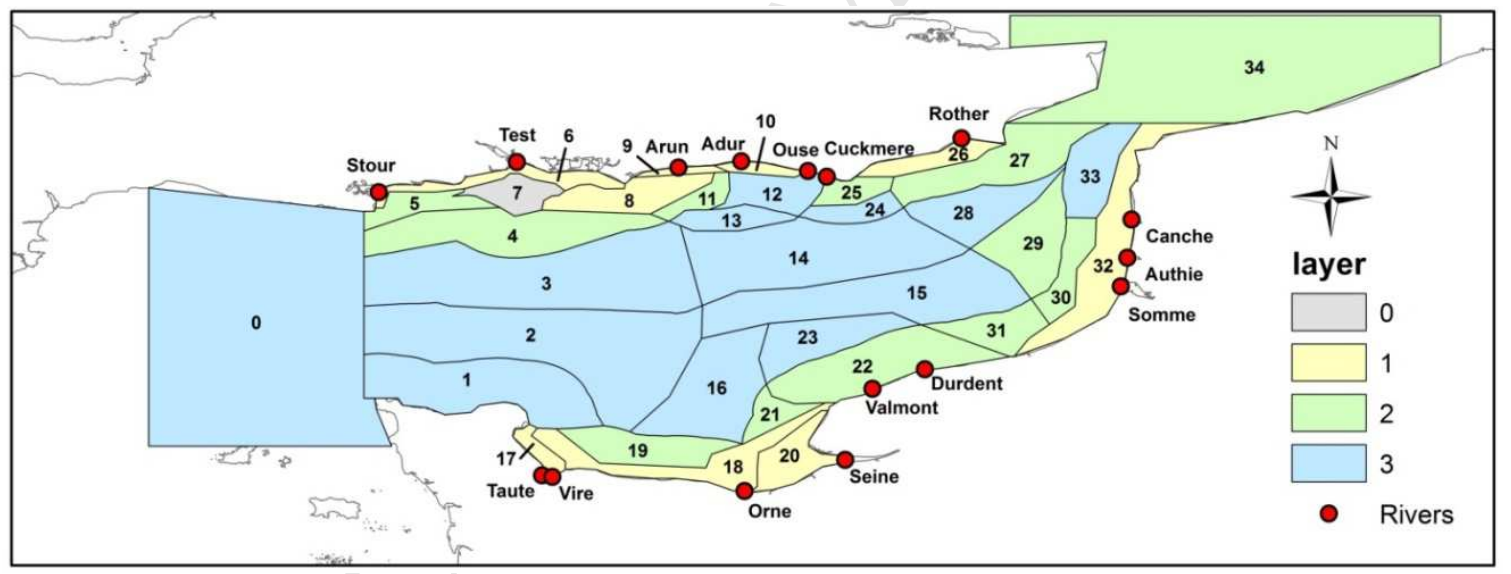


3)

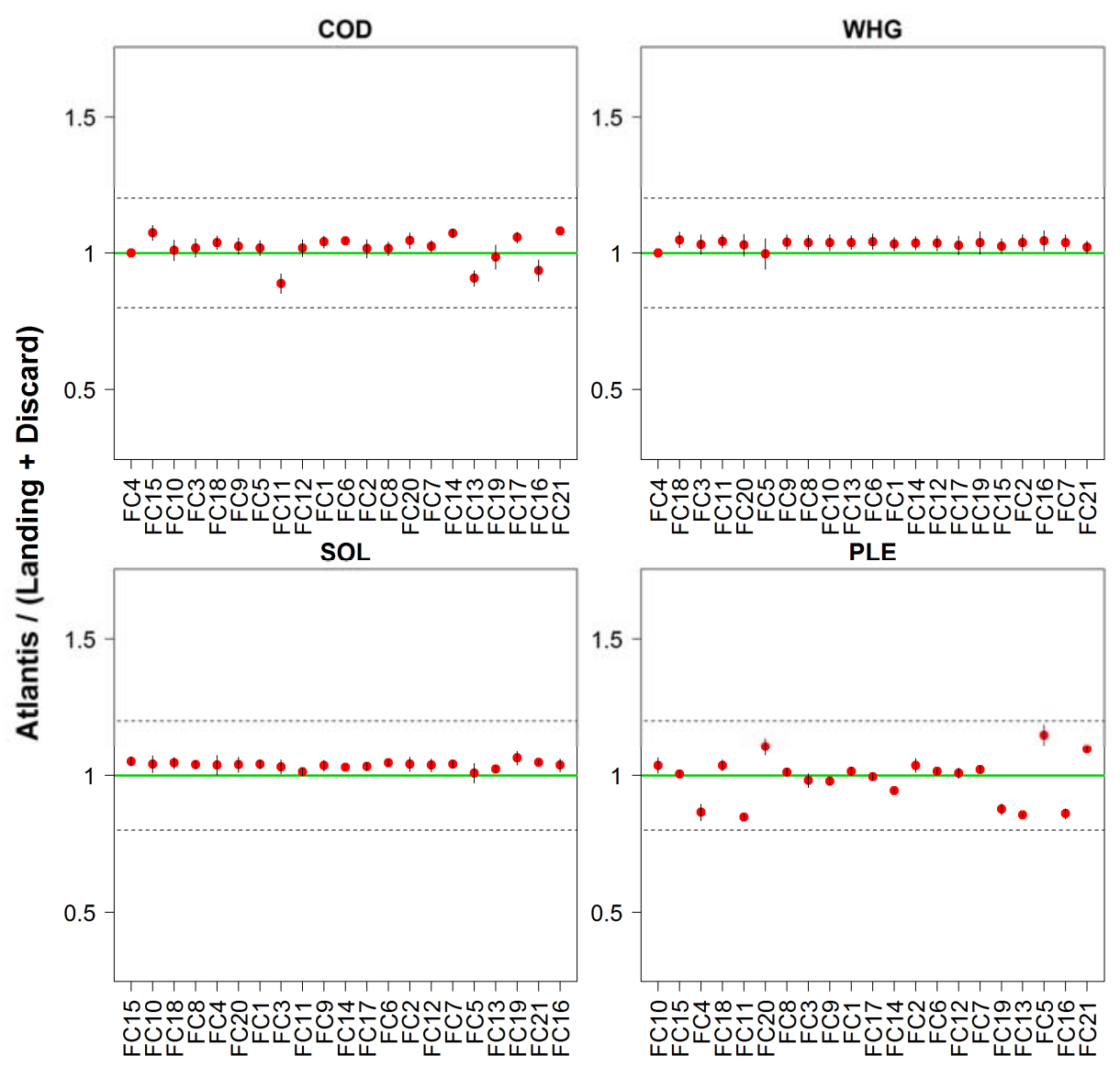

Fleets 
4)

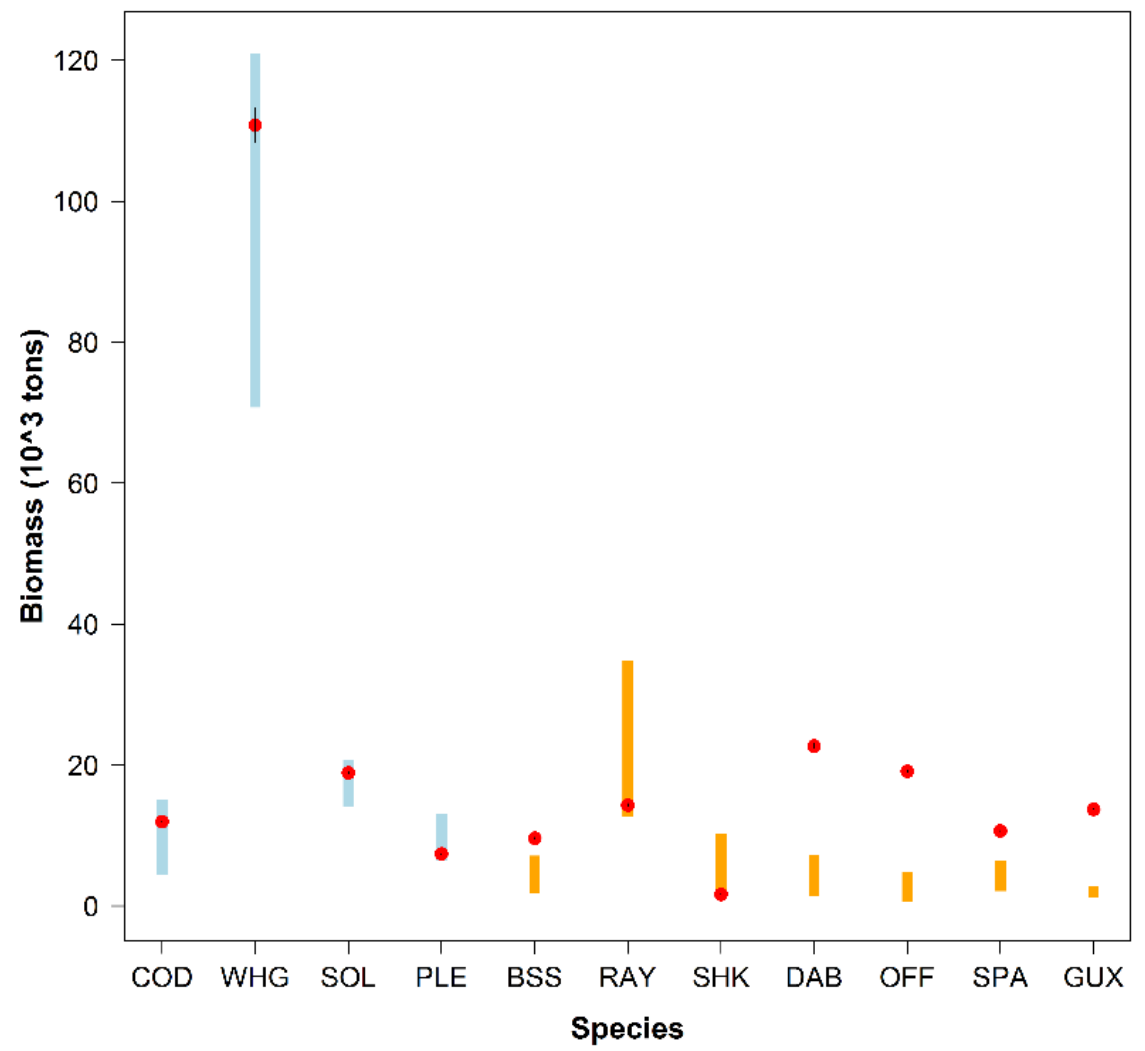


5)

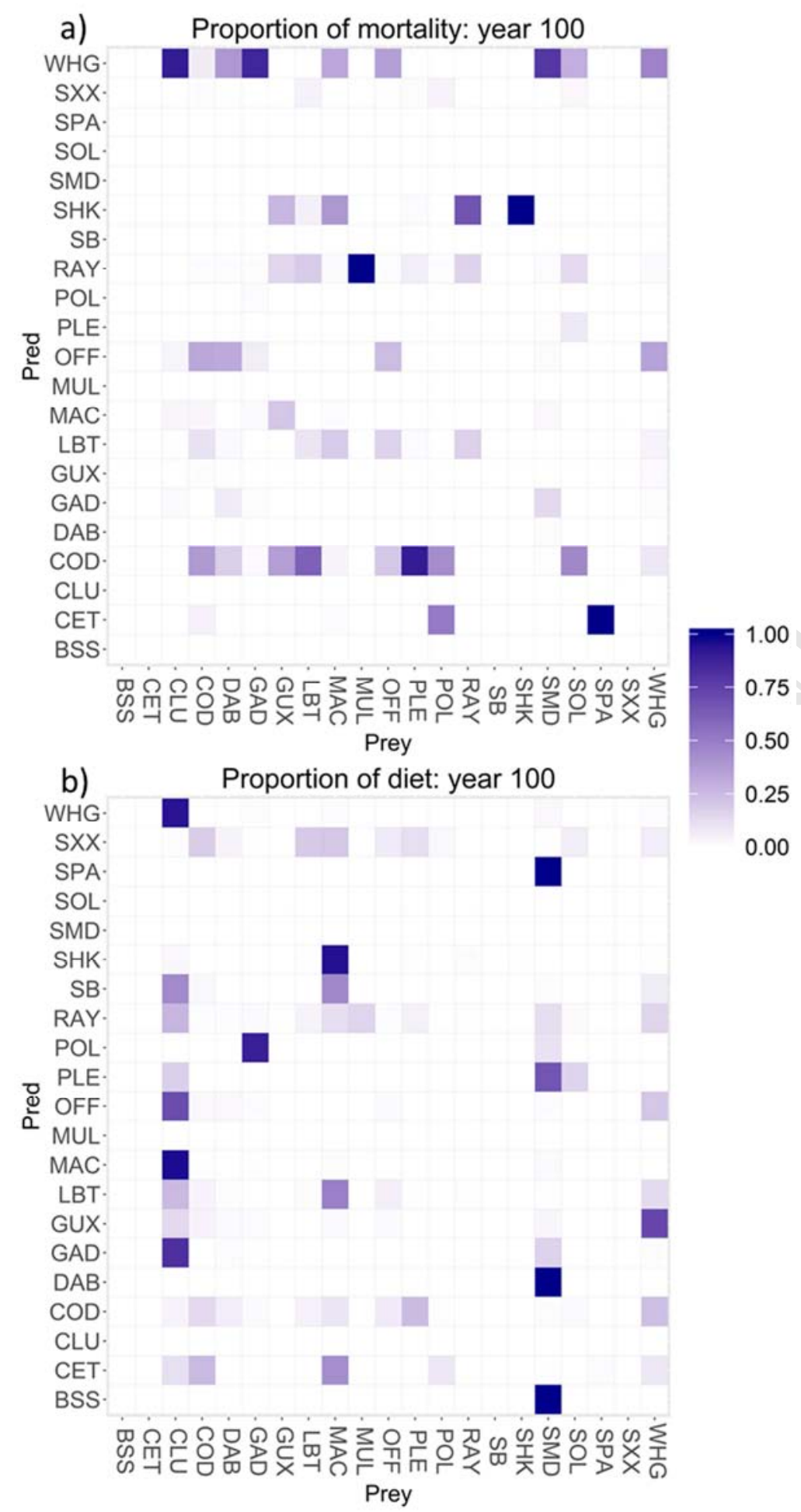


6)

a)

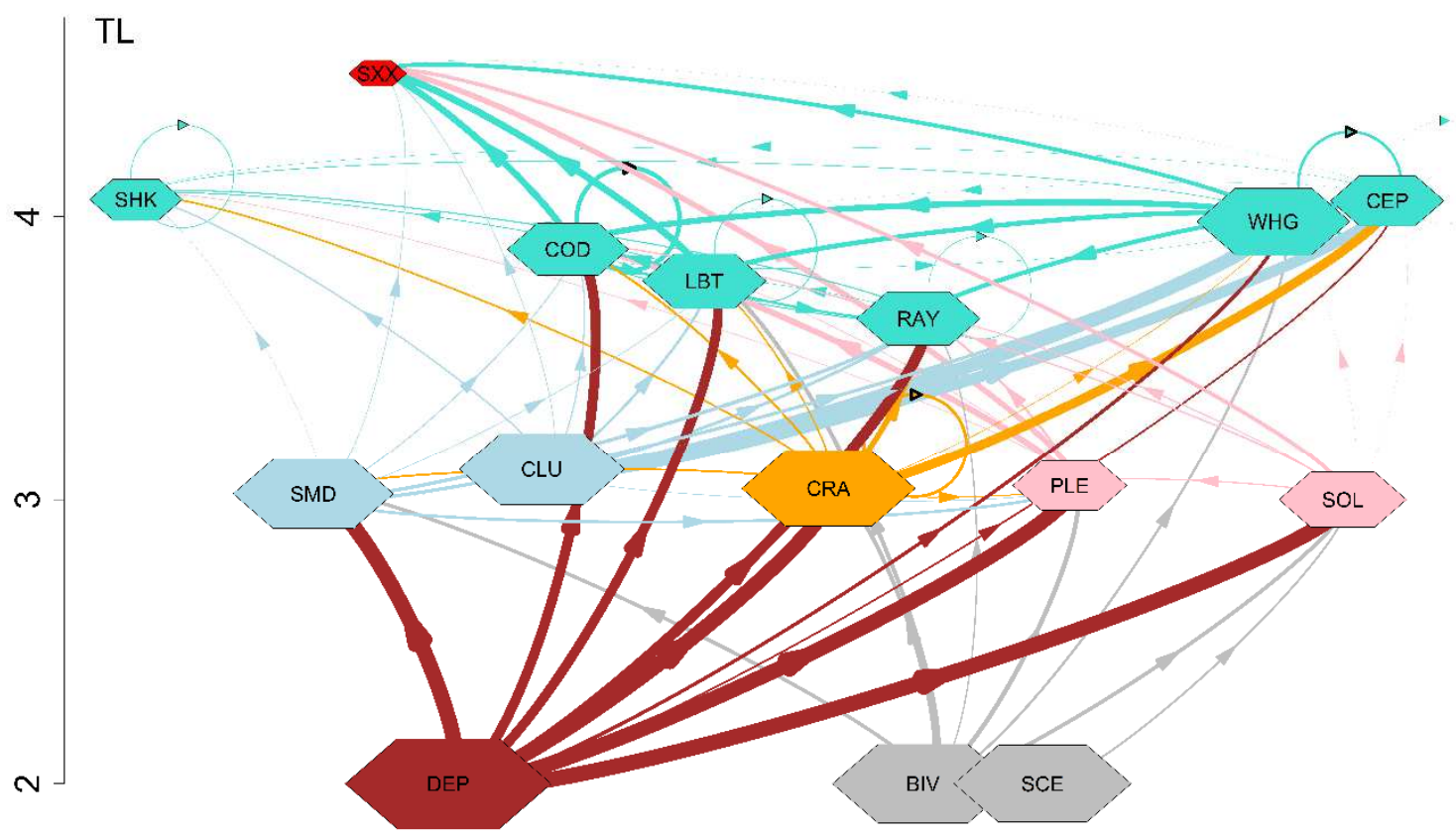

Proportions preys in predators diet

b)

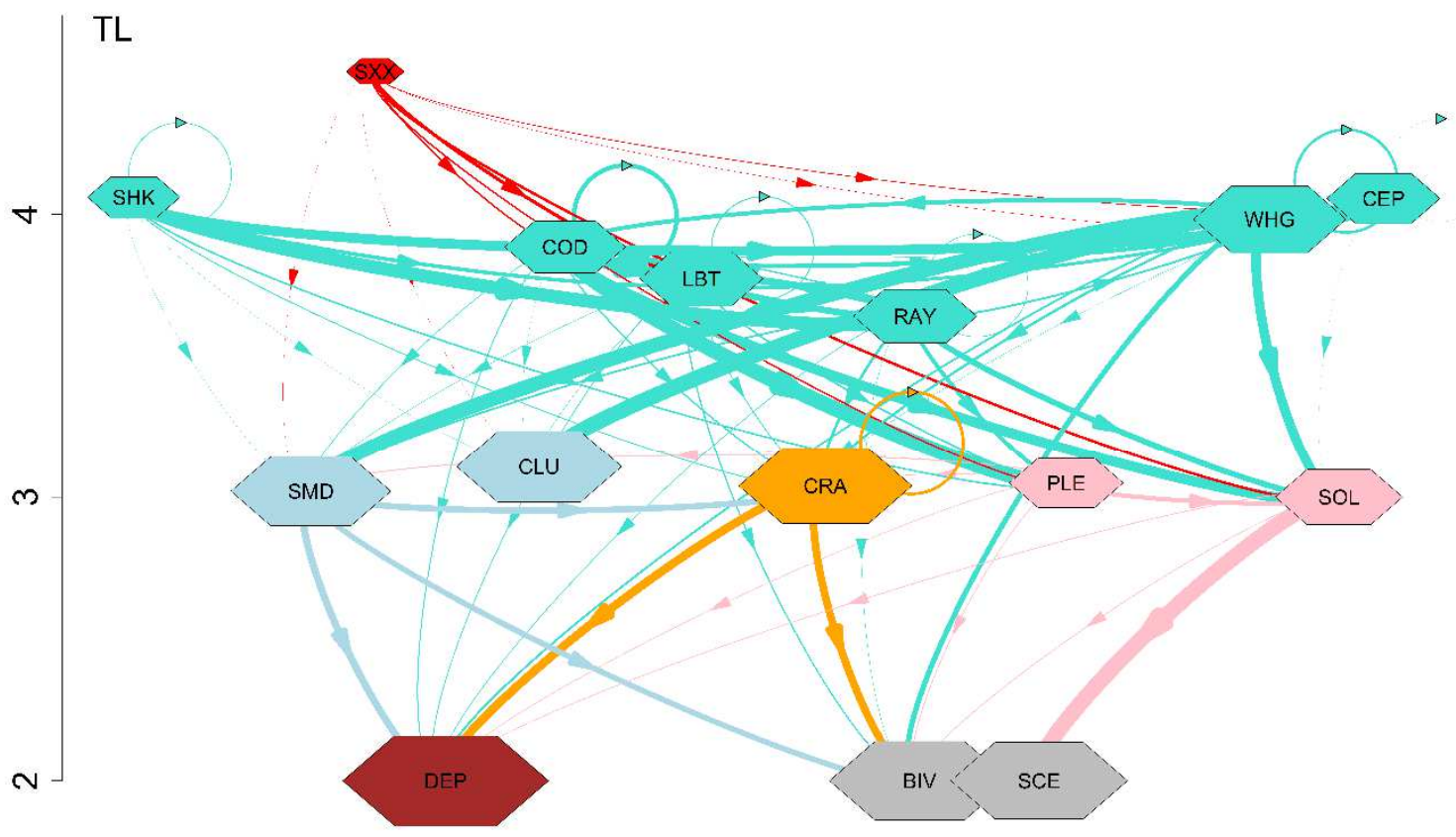

Impact of predators on preys 
7)

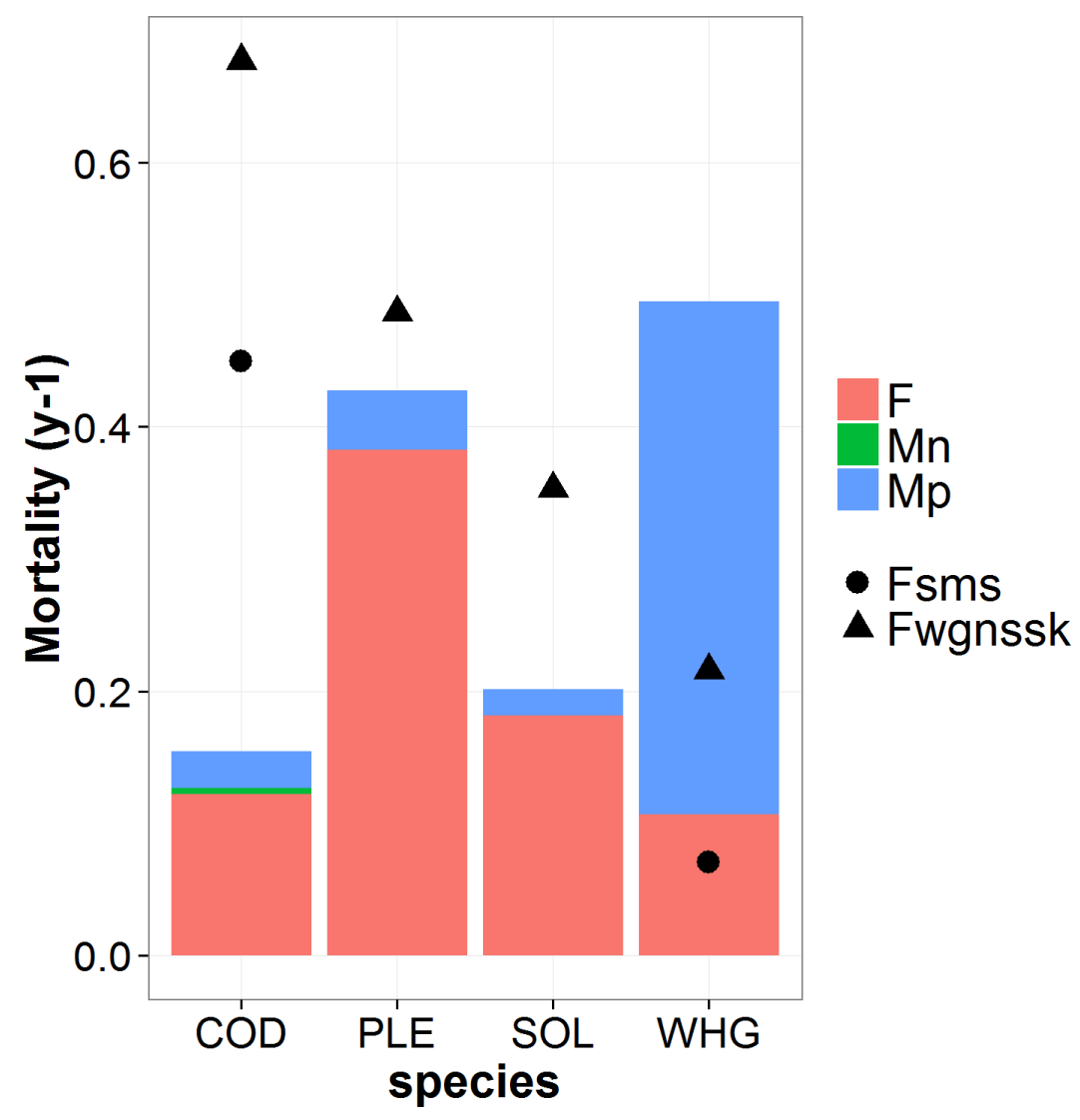

